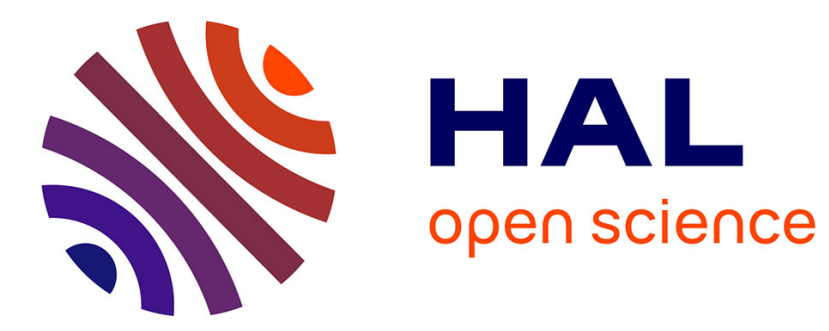

\title{
Evaluation of interrupter resistance in methacholine challenge testing in children
}

Marije Koopman, Hein J.L. Brackel, Anja A.P.H. Vaessen-Verberne, Wim Cj Hop, Cornelis K van Der Ent

\section{To cite this version:}

Marije Koopman, Hein J.L. Brackel, Anja A.P.H. Vaessen-Verberne, Wim Cj Hop, Cornelis K van Der Ent. Evaluation of interrupter resistance in methacholine challenge testing in children. Pediatric Pulmonology, 2010, 46 (3), pp.266. 10.1002/ppul.21362 . hal-00599815

\section{HAL Id: hal-00599815 https://hal.science/hal-00599815}

Submitted on 11 Jun 2011

HAL is a multi-disciplinary open access archive for the deposit and dissemination of scientific research documents, whether they are published or not. The documents may come from teaching and research institutions in France or abroad, or from public or private research centers.
L'archive ouverte pluridisciplinaire HAL, est destinée au dépôt et à la diffusion de documents scientifiques de niveau recherche, publiés ou non, émanant des établissements d'enseignement et de recherche français ou étrangers, des laboratoires publics ou privés. 


\section{Evaluation of interrupter resistance in methacholine challenge testing in children}

\begin{tabular}{|r|l|}
\hline Journal: & Pediatric Pulmonology \\
\hline Manuscript ID: & PPUL-10-0061.R2 \\
\hline Wiley - Manuscript type: & Original Article \\
\hline Author: & 08-Aug-2010 \\
\hline Complete List of Authors: & $\begin{array}{l}\text { Koopman, Marije; University Medical Center Utrecht, Wilhelmina } \\
\text { Children's Hospital, Pediatric Pulmonology } \\
\text { Brackel, Hein; Catharina Hospital, Pediatrics } \\
\text { Vaessen-Verberne, Anja; Amphia Hospital, Pediatrics } \\
\text { Hop, Wim CJ; Erasmus MC, Department of Epidemiology \& } \\
\text { Biostatistics } \\
\text { van der Ent, Cornelis; University Medical Center Utrecht, } \\
\text { Wilhelmina Children's Hospital, Pediatric Pulmonology }\end{array}$ \\
\hline Keywords: & $\begin{array}{l}\text { Bronchial hyperresponsiveness, bronchial provocation test, forced } \\
\text { expiratory volume in 1 second, interrupter resistance, methacholine } \\
\text { challenge test, sensitivity, specificity }\end{array}$ \\
\hline & \\
\hline
\end{tabular}


1 Title: Evaluation of interrupter resistance in methacholine challenge testing in children

2

3 Authors: Marije Koopman, $\mathrm{MD}^{1}$; Hein J.L. Brackel, MD, $\mathrm{PhD}^{2}$; Anja A.P.H. Vaessen-

4 Verberne, $\mathrm{MD}, \mathrm{PhD}^{3}$; Wim C. Hop, $\mathrm{PhD}^{4}$; Cornelis K. van der Ent, $\mathrm{MD}, \mathrm{PhD}^{1}$; on behalf of 5 the COMBO-Rint research group.

6

7 Institutions:

8 1. Department of Paediatric Pulmonology, Wilhelmina Children's Hospital, University

9 Medical Centre Utrecht, Utrecht, the Netherlands.

10 2. Department of Paediatrics, Catharina Hospital, Eindhoven, the Netherlands.

11 3. Department of Paediatrics, Amphia Hospital, Breda, the Netherlands

12 4. Department of Biostatistics, Erasmus MC - University Medical

13 Centre Rotterdam, Rotterdam, the Netherlands

14

15 COMBO-Rint research group consists of: H.G.M. Arets, N.J. van den Berg, P.L.P. Brand,

16 E.J. Duiverman, H.J. Hendriks, J.W.C.M. Heynens, J.C. van Nierop, M. Nuysink.

17

18 Corresponding author

19 Ms. Marije Koopman

20 Wilhelmina Children's Hospital/University Medical Centre Utrecht

21 Department of Paediatric Pulmonology, Huispostnummer KH.01.419.0

22 P O Box 85090, 3508 AB Utrecht, the Netherlands

23 Email: M.Koopman-5@umcutrecht.nl

24 Telephone number: 0031-88-7553201 / Fax number: 0031-88-7554747 
26 Word count body of manuscript: 2483

27

28 Financial support: This study was supported by an unconditional grant from

29 GlaxoSmithKline Pharma Europe.

30

31 This article has supplementary material.

32

33 Running head: $\mathrm{R}_{\text {int }}$ in bronchial challenge testing 
34

35

36

\section{SUMMARY}

Bronchial hyperresponsiveness is a key feature of asthma and is assessed using bronchial provocation tests. The primary outcome in such tests (a 20\% decrease in forced expiratory volume in 1 second $\left.\left(\mathrm{FEV}_{1}\right)\right)$ is difficult to measure in young patients. This study evaluated the sensitivity and specificity of the interrupter resistance $\left(\mathrm{R}_{\text {int }}\right)$ technique, which does not require active patient participation, by comparing it to the primary outcome measure.

Methacholine challenge tests were performed in children with a history of moderate asthma and bronchial hyperresponsiveness. Mean and individual changes in $\mathrm{R}_{\text {int }}$ and $\mathrm{FEV}_{1}$ were studied. A receiver operating characteristic (ROC) curve was used to describe sensitivity and specificity of $\mathrm{R}_{\text {int }}$.

Seventy-three children (median age: 9.2 yrs; range: 6.3- 13.4 yrs) participated. There was a significant $(\mathrm{p}<0.01)$ increase in mean $\mathrm{R}_{\mathrm{int}}$ with increasing methacholine doses.

However, individual changes of $\mathrm{R}_{\mathrm{int}}$ showed large fluctuations. There was great overlap in change of $\mathrm{R}_{\text {int }}$ between children who did and did not reach the $\mathrm{FEV}_{1}$ endpoint. A ROC-curve showed an area under the curve of 0.65 .

Because of low sensitivity and specificity, the use of $\mathrm{R}_{\text {int }}$ to diagnose bronchial hyperresponsiveness in individual patients seems limited.

\section{Word count abstract: 190}

Key words: Bronchial hyperresponsiveness, bronchial provocation test, forced expiratory volume in 1 second, interrupter resistance, methacholine challenge test, sensitivity, specificity. 


\section{INTRODUCTION}

60 According to GINA guidelines bronchial hyperresponsiveness (BHR) is a key feature of 61 asthma (1). To objectify BHR, forced flow volume manoeuvres are required to measure the 62 forced expiratory volume in one second $\left(\mathrm{FEV}_{1}\right)$, as primary outcome measure in bronchial 63 challenge testing (2). Because of the difficulty of obtaining forced lung function

64 measurements in early childhood the diagnosis of asthma in this age group is challenging and 65 complicated. Several studies have advocated measurement of the interrupter resistance $\left(\mathrm{R}_{\mathrm{int}}\right)$ 66 as an alternative to quantify airway obstruction in preschool children and in children with 67 developmental delay $(3 ; 4)$. The interrupter technique is non-invasive and can be obtained 68 during tidal breathing (5). $\mathrm{R}_{\text {int }}$ can be measured in children from two years of age as it 69 requires minimal cooperation (6). The $\mathrm{R}_{\text {int }}$ technique has been compared to body 70 plethysmography (7) and transcutaneous partial pressure of oxygen measurements (7-10) 71 during methacholine challenge tests, but most studies made no comparison with the outcome 72 measure $\mathrm{FEV}_{1}$. The one study that compared $\mathrm{R}_{\text {int }}$ with $\mathrm{FEV}_{1}$ during methacholine challenge 73 testing reported a mean increase in $\mathrm{R}_{\text {int }}$ with increasing doses of methacholine (11). However, 74 this study did not present the changes in $\mathrm{R}_{\mathrm{int}}$ for individual patients nor how these related to 75 individual changes in $\mathrm{FEV}_{1}$. The ability of $\mathrm{R}_{\mathrm{int}}$ to detect methacholine induced 76 bronchoconstriction in individual patients, as measured by a $20 \%$ decrease in $\mathrm{FEV}_{1}$, has never 77 been studied.

78 The latest ATS/ERS statement on pulmonary function testing in preschool children 79 recommended the need to determine the role of $\mathrm{R}_{\text {int }}$ in bronchial challenge tests (5). The 80 current study evaluated the sensitivity and specificity of $R_{\text {int }}$ to detect airflow obstruction 81 during methacholine challenge tests in asthmatic children by comparing measurements with $82 \mathrm{FEV}_{1}$ as the gold standard. 
MATERIALS AND METHODS

84

This study was a substudy of the multicentre COMBO-study in children between 6 and 16 years with moderate asthma (see online supplement) (12). Nine out of 19 hospitals performed additional $\mathrm{R}_{\text {int }}$ measurements during methacholine challenge tests. The children from these centres were included in this substudy. It was approved by the local medical ethical committees and written informed consent was obtained from the parents (and the child if $\geq 12$ years) before start of the study. For additional information see online supplement.

\section{Study protocol}

Methacholine provocation tests were performed twice (at start of study and after 26 weeks) measuring $\mathrm{R}_{\text {int }}$ and $\mathrm{FEV}_{1}$ after each methacholine dose. All children abstained from longacting $\beta 2$ agonists and inhaled steroids for 12 hours before the first methacholine provocation test (and 36 hours before the second methacholine provocation test), and from short acting $\beta 2$ agonists for 6 hours before provocation testing. To prevent possible, unwanted physiologic effects of deep inhalation on $\mathrm{R}_{\mathrm{int}}, \mathrm{R}_{\mathrm{int}}$ was measured prior to $\mathrm{FEV}_{1}$. Pulmonary function tests were performed to conform with latest ATS/ERS guidelines $(2 ; 5 ; 13)$ and briefly described below. The complete methodology is described in the online supplement.

\section{Methacholine challenge testing}

Methacholine challenge tests were performed using the dosimeter method $(2 ; 14)$ with a nebulizer (model 646, DeVilbiss Healthcare, Somerset, USA) attached to a dosimeter (Rosenthal French dosimeter, PDS Instrumentation, Louisville CO, USA). Methacholine chloride was administered in doubling doses and provocation was continued after at least five minutes and until the dose at which at least $20 \%$ fall in $\mathrm{FEV}_{1}\left(\mathrm{PD}_{20}\right)$ or the maximum dose was reached. 
Interrupter resistance

110 Airway resistance measurements were carried out using the MicroRint (Micro Medical

111 Limited, Kent, UK). A bacterial filter was used (Spirosafe bacterial filter, Micro Medical,

112 Kent, UK). Reference values of Merkus et al. (15) were used.

114 Spirometry

115 Maximal expiratory flow-volume measurements were performed with standardized

116 equipment, using reference values of Stanojevic (16).

118 Analysis

119 Changes in $\mathrm{FEV}_{1}$ and $\mathrm{R}_{\text {int }}$ were analyzed as percentages change from baseline. Change in $\mathrm{R}_{\text {int }}$ 120 was also assessed as change in percentage predicted and change in z-score, computed from

121 the latest $\mathrm{R}_{\text {int }}$ reference values (15). Wilcoxon Signed Ranks test was used to investigate

122 whether there was a significant increase in mean change from baseline of $\mathrm{R}_{\text {int }}$ at each dose

123 step. To quantify the variability of $\mathrm{FEV}_{1}$ and $\mathrm{R}_{\text {int }}$ within individuals between the various

124 dosesteps, coefficients of variation (CV) were calculated (see online supplement for

125 calculation). The resulting individual paired CV's of $\mathrm{FEV}_{1}$ and $\mathrm{R}_{\mathrm{int}}$ were compared using

126 Wilcoxon's test. Comparison of mean CV's between centers was done using the Kruskal-

127 Wallis test. The association between changes in $\mathrm{FEV}_{1}$ and changes in $\mathrm{R}_{\text {int }}$ at $\mathrm{PD}_{20}$ was

128 analysed using Spearman's correlation $\left(\mathrm{r}_{\mathrm{S}}\right)$. At each separate dose step Mann Whitney tests

129 were computed to compare the difference in changes from baseline between subjects who did

130 and who did not reach the $\mathrm{PD}_{20}$ endpoint at the dose step. Cox regression, with change from

131 baseline of $\mathrm{R}_{\mathrm{int}}$ as time-dependent variable, was used to analyse whether these changes were

132 predictive for having reached the $\mathrm{PD}_{20}$ endpoint at the subsequent dose steps. The sensitivity 
1

3

4

5

6

7

8

10

11

12

13

14

15

16

17

18

19

20

21

22

133 and specificity of $R_{\text {int }}$ in relation to having reached $F E V_{1}$-based $\mathrm{PD}_{20}$ was described by

134 receiver operating characteristic (ROC) curves. The area under the curve (AUC) shows

135 whether the change in $\mathrm{R}_{\text {int }}$ can correctly classify those who do and do not reach the $\mathrm{PD}_{20}$

136 endpoint. We used the coefficient of repeatability calculated by Beydon et al. (a 32.1\%

137 increase in $\mathrm{R}_{\text {int }}$ ) as a cut-off value to calculate the sensitivity and specificity of $\mathrm{R}_{\text {int }}$ to predict a $13820 \%$ fall in $\mathrm{FEV}_{1}$.

139

140

141 


\section{RESULTS}

143 At the first COMBO-study visit 73 children with moderate asthma (60\% boys) with a median

144 age of 9.2 years (range: 6.3 - 13.4 years) performed both $R_{\text {int }}$ and $F E V_{1}$ measurements during

145 methacholine challenge. Baseline characteristics are shown in Table 1. Fifty-two children

146 reached the $\mathrm{PD}_{20}$ endpoint and were defined as responders (Table 2).

147 There was a significant increase from baseline of $\mathrm{R}_{\mathrm{int}}$ starting at the sixth methacholine

148 dose step and all dose steps thereafter (all $\mathrm{p}<0.01$ ). From the first dose step mean $\mathrm{FEV}_{1}$ was

149 significantly different from baseline value (all $\mathrm{p}<0.01$ ), except for dose step 2 . Visual

150 inspection of individual $\mathrm{R}_{\text {int }}$ profiles during the challenge test showed large fluctuations with

151 rises and falls at subsequent dose steps. In contrast, much smoother profiles with gradual falls

152 were found for $\mathrm{FEV}_{1}$ (see E-figure 1 in the online supplement). To express the variability in

153 individual curves, the $\mathrm{CV}$ of measured values was calculated per patient. For $\mathrm{R}_{\text {int }}$ the mean

$154 \mathrm{CV}$ of all patients was $10.6 \%\left(10^{\text {th }}-90^{\text {th }}\right.$ percentile: $\left.5.5 \%-16.3 \%\right)$. The mean CV for FEV 1

155 was significantly smaller: $2.9 \%(1.7 \%-4.3 \%, \mathrm{p}<0.001)$. Further analysis of CV $\mathrm{R}_{\text {int }}$ showed

156 that there was no correlation with age $\left(r_{S}=-0.13, p=0.26\right)$. Also centres did not significantly

157 differ from each other (Kruskal-Wallis test: $\mathrm{p}=0.17$ ).

158 Analysing the 52 children who reached the $\mathrm{PD}_{20}$ endpoint, there was no significant

159 correlation between changes from baseline of $\mathrm{FEV}_{1}$ and changes from baseline of $\mathrm{R}_{\mathrm{int}}$ at the

160 last dose step at which the $\mathrm{PD}_{20}$ endpoint was reached $\left(\mathrm{r}_{\mathrm{S}}=0.11, \mathrm{p}=0.44\right)$.

161 Figure 1 demonstrates the mean changes from baseline of $\mathrm{FEV}_{1}$ and $\mathrm{R}_{\text {int }}$ at each dose

162 step, while at each dose step patients are grouped according to whether or not the $\mathrm{PD}_{20}$

163 endpoint was reached at the dose step. At none of the dose steps there was a significant

164 difference in the mean change of $\mathrm{R}_{\mathrm{int}}$ from baseline between those who reached the $\mathrm{PD}_{20}$

165 endpoint at that dose step versus those who did not, except at dose step 6 ( $\mathrm{p}=0.014$ ) (figure

166 1B). A combined analysis of all dose steps comparing responders and non-responders, using 
167 Cox regression analysis, showed that a greater change of $\mathrm{R}_{\mathrm{int}}$ was associated with a higher

168 probability of reaching the $\mathrm{PD}_{20}$ endpoint $(\mathrm{p}=0.038)$. However, when inspecting the

169 individual changes from baseline, there is large overlap of children who did and who did not

170 reach the $\mathrm{PD}_{20}$ endpoint at the various dose steps (Figure 2). A ROC curve of changes from

171 baseline of $\mathrm{R}_{\text {int }}$ as a measure to detect a $20 \%$ decrease in $\mathrm{FEV}_{1}$ is shown in Figure 3, resulting

172 in a small AUC of 0.65.

173 When using a $32.1 \%$ increase in $\mathrm{R}_{\text {int }}$ as cut-off value to calculate the sensitivity and

174 specificity of $\mathrm{R}_{\text {int }}$ to predict a $20 \%$ fall in $\mathrm{FEV}_{1}$, we found a sensitivity of $50 \%$ and a

175 specificity of $43 \%$. This means that $\mathrm{R}_{\text {int }}$ was able to detect half of the responders as

176 determined by PD20 and that in 12 out of 21 children $\mathrm{R}_{\text {int }}$ increased with more than $32 \%$

177 without a concomitant fall of $\mathrm{FEV}_{1}$ with $20 \%$.

178 Repeating all analyses with change in $\mathrm{R}_{\text {int }}$ expressed as change in percentage predicted

179 and change in z-score led to similar results (data not shown). AUC's of ROC curves for

180 change in percentage predicted and for change in z-score were both 0.66.

181 In 64 children the methacholine challenge test was repeated after 26 weeks. The

182 analyses to compare $\mathrm{R}_{\text {int }}$ with $\mathrm{FEV}_{1}$ (as described above) showed similar results (data not

183 shown). The AUC of the ROC curve was 0.61.

184

185

John Wiley \& Sons, Inc. 
186

187

188

189

190

191

192

193

194

195

196

197

198

199

200

201

202

203

204

205

206

207

208

209

210

\section{DISCUSSION}

This study showed that, although there was a significant increase of mean $\mathrm{R}_{\text {int }}$ values with higher doses of methacholine, individual changes in $\mathrm{R}_{\text {int }}$ are highly variable during

methacholine challenge. The sensitivity and specificity of $\mathrm{R}_{\text {int }}$ to detect methacholine induced bronchoconstriction is low, which might limit the use of $\mathrm{R}_{\mathrm{int}}$ in individual patients.

Several studies evaluated lung function measures requiring less patient effort than $\mathrm{FEV}_{1}$, which could possibly be used as alternative measures of changes in bronchoconstriction. Klug et al showed that $R_{\text {int }}$ was significantly less sensitive than specific airway resistance in detecting changes in airway function (7). Phagoo et al found that $R_{\text {int }}$ was also less sensitive and showed more variability than transcutaneous partial pressure of oxygen measurements $(9 ; 10)$. In a study of Beydon et al. the majority of children with a $20 \%$ fall in transcutaneous partial pressure of oxygen $\left(\mathrm{PD}_{20} \mathrm{P}_{t c} \mathrm{O}_{2}\right)$ showed a significant change of $\mathrm{R}_{\text {int }}$ during methacholine challenge. However, all children who did not reach the $\mathrm{PD}_{20} \mathrm{P}_{\mathrm{tc}} \mathrm{O}_{2}$ had at least once a significant change from baseline (8), resulting in many false positive as well as false negative outcomes.

Despite these data $\mathrm{R}_{\text {int }}$ is still advocated as an alternative measure for airway obstruction in those who are not able to perform forced breathing manoeuvres. Several studies showed significant correlation between gold standard $\mathrm{FEV}_{1}$ and $\mathrm{R}_{\mathrm{int}}$ in groups of patients $(4 ; 6)$, and reference values for $\mathrm{R}_{\text {int }}$ measurement in healthy controls have been published (15;17-20). Although there is convincing evidence on the value of $R_{\text {int }}$ measurement as a measure of airway obstruction in groups of patients, the sensitivity of $\mathrm{R}_{\mathrm{int}}$ to detect changes in airway obstruction in individual patients has been little researched. Only one previous study compared $\mathrm{R}_{\text {int }}$ with $\mathrm{FEV}_{1}$ during methacholine challenge testing (11) and found that on average $\mathrm{R}_{\text {int }}$ increased during methacholine challenge comparable to changes in $\mathrm{FEV}_{1}$ measurements, but individual changes in $\mathrm{R}_{\text {int }}$ were not shown. Kannisto et al. compared $\mathrm{R}_{\text {int }}$ 
211 with $\mathrm{FEV}_{1}$ during exercise challenge to diagnose BHR (21). However, in this study only 11 212 (22\%) children reached the $\mathrm{R}_{\text {int }}$ endpoint (15\% increase from baseline) and only 6 of them 213 also reached the $\mathrm{FEV}_{1}$ endpoint (10\% decrease from baseline). The children who showed a $21415 \%$ rise in $R_{\text {int }}$ but who did not have a $10 \%$ decrease in $\mathrm{FEV}_{1}$ could be misclassified by $\mathrm{R}_{\text {int }}$ 215 as having BHR. Davies et al. investigated the correlation between $\mathrm{R}_{\mathrm{int}}$ and $\mathrm{FEV}_{1}$ in 216 bronchodilator response, and despite a correlation between $F E V_{1}$ and $R_{\text {int }}$ in a group of 217 patients, they found no significant correlation in individual children (22).

218 To evaluate the sensitivity and specificity of the $\mathrm{R}_{\text {int }}$ technique to detect changes in 219 airway obstruction in individual children we performed simultaneous measurements of $\mathrm{R}_{\mathrm{int}}$ 220 and gold standard $\mathrm{FEV}_{1}$ in a large group of children with asthma. We show that in individual 221 cases the variability of $\mathrm{R}_{\text {int }}$ measurements is high (mean intra-patient $\mathrm{CV} 10.6 \%$ ), precluding 222 proper prediction of changes in $\mathrm{FEV}_{1}$. In the present study the ROC curve, describing the 223 sensitivity and specificity of $\mathrm{R}_{\text {int }}$ in detecting BHR as determined by the primary outcome $224 \mathrm{FEV}_{1}$, had a small AUC of 0.65 . This predictive capacity is lower compared to impulse 225 oscillometry (AUC 0.68 to $0.75(23)$ ).

226 Large individual fluctuations in $\mathrm{R}_{\text {int }}$ might be due to large intrapatient short-term 227 variation in airway resistance during tidal breathing $(11 ; 17 ; 20 ; 24)$. This variability, resulting 228 in low sensitivity and specificity, could limit the ability to detect thresholds in individual 229 airway obstruction as required in clinical practice. Furthermore the sensitivity might be lower 230 compared to $\mathrm{FEV}_{1}$ because during (severe) airflow obstruction equilibration of alveolar 231 pressure might take longer than is realised during the shutter closure time during $R_{\text {int }}$ 232 measurement (25). This may explain the lower $\mathrm{R}_{\text {int }}$ values in case of (severe) peripheral 233 airway obstruction and hence lead to misclassifications during methacholine challenge 234 testing. A third explanation of high variability of $\mathrm{R}_{\text {int }}$ might be the variability of upper airway 
235 resistance. Proper positioning of the head and neck and adequate support of the cheeks is 236 highly warranted and might lead to intra-individual variability.

237 The findings of our study imply that on group level BHR can be documented, since we

238 showed on average a significant rise in $\mathrm{R}_{\text {int }}$ with increasing methacholine doses. This may be

239 useful in epidemiologic research. However, $\mathrm{R}_{\text {int }}$ seems to have insufficient capacity to

240 diagnose BHR in individual patients and therefore it is of limited value in BHR measurements

241 in clinical practice.

242 A major strength of our study is the fact that the methacholine challenge test was

243 repeated after 26 weeks and resulted in a similarly low sensitivity and specificity of $R_{\text {int }}$,

244 which validated the results. Beside this, the present study may have some limitations. Firstly,

245 the study was performed in children with a mean age of 9.3 years, because preschool children

246 are seldom able to perform $\mathrm{FEV}_{1}$ measurements. It could be questioned if the found results

247 are applicable to younger children. Since $\mathrm{R}_{\mathrm{int}}$ is a measure of total airway resistance, an

248 induced bronchoconstriction will lead to a relative larger increase in $\mathrm{R}_{\text {int }}$ in young children

249 compared to older children, because in young children lower airways resistance contributes

250 more to total airway resistance (26). Nevertheless, the fluctuations in $\mathrm{R}_{\text {int }}$ are expected to be

251 similar as the short term repeatability of $R_{\text {int }}$ that has been found to be independent of age

252 (20;27). Additionally we used a 20\% fall as 'gold standard' in detecting methacholine induced

253 bronchoconstriction. When we used a $32 \%$ increase in $\mathrm{R}_{\text {int }}$ (the coefficient of repeatability of

$254 \mathrm{R}_{\text {int }}$ measurements as described by Beydon et al.) as a cut-off value to determine BHR, there

255 were 12 children with a significant change in $R_{\text {int }}$ but without a $20 \%$ fall in $\mathrm{FEV}_{1}$. The

256 pathophysiology of a fall in $\mathrm{FEV}_{1}$ during a forced manoeuvre might be different from an

257 increase of $\mathrm{R}_{\mathrm{int}}$ during tidal breathing. Therefore, there is a possibility that $\mathrm{FEV}_{1}$ might not be

258 the gold standard for bronchial challenges especially in young children. 
1 4

7

8

$260 \mathrm{FEV}_{1}$ but who did have a significant increase in $\mathrm{R}_{\text {int. }}$ This might have resulted in too low

261 sensitivity because of too many false positives. However, $\mathrm{FEV}_{4}$ is the primary outcome in

262 methacholine challenge test, and no better 'gold standard' is available.

263 The current study showed on average an increase of $R_{i n t}$ with subsequent methacholine

264 doses during methacholine challenge tests and therefore it might be useful as a measure of

265 airflow obstruction in groups of patients, e.g. in large epidemiological studies. However, we

266 conclude that $\mathrm{R}_{\text {int }}$ seems to have insufficient capacity to diagnose BHR in individual patients. 


\section{ACKNOWLEDGEMENTS}

270 The authors would like to thank the lung function technicians for the measurements and the

271 members of the COMBO- $\mathrm{R}_{\text {int }}$ research group for recruiting the patients. The COMBO- $\mathrm{R}_{\text {int }}$

272 research group consists of: H.G.M. Arets (University Medical Centre Utrecht), N.J. van den

273 Berg (Flevo Hospital Almere), P.L.P. Brand (Princess Amalia Children's Hospital Zwolle),

274 E.J. Duiverman (University Medical Centre Groningen), H.J. Hendriks (Maastricht University

275 Medical Centre), J.W.C.M. Heynens (Maasland Hospital Sittard), J.C. van Nierop

276 (Academical Medical Centre Amsterdam), M. Nuysink (Juliana Children's Hospital).

277 HJL Brackel has received fees for consulting and for speaking from GlaxoSmithKline Pharma 278 Europe.

279

280 


\section{REFERENCES}

1. Bateman ED, Hurd SS, Barnes PJ, Bousquet J, Drazen JM, FitzGerald M, Gibson P,

Ohta K, O'Byrne P, Pedersen SE, Pizzichini E, Sullivan SD, Wenzel SE, Zar HJ.

Global strategy for asthma management and prevention: GINA executive summary. Eur Respir J 2008 January;31(1):143-78.

2. Crapo RO, Casaburi R, Coates AL, Enright PL, Hankinson JL, Irvin CG, MacIntyre NR, McKay RT, Wanger JS, Anderson SD, Cockcroft DW, Fish JE, Sterk PJ. Guidelines for methacholine and exercise challenge testing-1999. This official statement of the American Thoracic Society was adopted by the ATS Board of Directors, July 1999. Am J Respir Crit Care Med 2000 January;161(1):309-29.

3. Beydon N, Pin I, Matran R, Chaussain M, Boule M, Alain B, Bellet M, Amsallem F, Alberti C, Denjean A, Gaultier C. Pulmonary function tests in preschool children with asthma. Am J Respir Crit Care Med 2003 September 15;168(6):640-4.

4. Black J, Baxter-Jones AD, Gordon J, Findlay AL, Helms PJ. Assessment of airway function in young children with asthma: comparison of spirometry, interrupter technique, and tidal flow by inductance plethsmography. Pediatr Pulmonol 2004 June;37(6):548-53.

5. Beydon N, Davis SD, Lombardi E, Allen JL, Arets HG, Aurora P, Bisgaard H, Davis GM, Ducharme FM, Eigen H, Gappa M, Gaultier C, Gustafsson PM, Hall GL, Hantos Z, Healy MJ, Jones MH, Klug B, Lodrup Carlsen KC, McKenzie SA, Marchal F, Mayer OH, Merkus PJ, Morris MG, Oostveen E et al. An official American Thoracic Society/European Respiratory Society statement: pulmonary function testing in preschool children. Am J Respir Crit Care Med 2007 June 15;175(12):1304-45. 
305 6. Arets HG, Brackel HJ, van der Ent CK. Applicability of interrupter resistance

306 measurements using the MicroRint in daily practice. Respir Med 2003

$307 \quad$ April;97(4):366-74.

308 7. Klug B, Bisgaard H. Measurement of lung function in awake 2-4-year-old asthmatic 309 children during methacholine challenge and acute asthma: a comparison of the 310 impulse oscillation technique, the interrupter technique, and transcutaneous 311 measurement of oxygen versus whole-body plethysmography. Pediatr Pulmonol 1996 $312 \quad$ May;21(5):290-300.

313 8. Beydon N, Trang-Pham H, Bernard A, Gaultier C. Measurements of resistance by the 314 interrupter technique and of transcutaneous partial pressure of oxygen in young 315 children during methacholine challenge. Pediatr Pulmonol 2001 March;31(3):238-46.

316 9. Phagoo SB, Wilson NM, Silverman M. Evaluation of the interrupter technique for 317 measuring change in airway resistance in 5-year-old asthmatic children. Pediatr 318 Pulmonol 1995 December;20(6):387-95.

319 10. Phagoo SB, Wilson NM, Silverman M. Evaluation of a new interrupter device for 320 measuring bronchial responsiveness and the response to bronchodilator in 3 year old 321 children. Eur Respir J 1996 July;9(7):1374-80.

322 11. Bisgaard H, Klug B. Lung function measurement in awake young children. Eur Respir $323 \quad J 1995$ December;8(12):2067-75.

324 12. Vaessen-Verberne A.A.P.H., Berg van den N.J., Nierop van J.C., Brackel H.J.L., 325 Gerrits G.P.J.M., Hop W.C.J., Duiverman E.J. Combination therapy 326 salmeterol/fluticasone versus doubling dose of fluticasone in 327 children with asthma. Am.J.Respir.Crit Care Med. 2010 Jul 9. [Epub ahead of print] 
328 13. Miller MR, Hankinson J, Brusasco V, Burgos F, Casaburi R, Coates A, Crapo R, 329 Enright P, van der Grinten CP, Gustafsson P, Jensen R, Johnson DC, MacIntyre N, 330 McKay R, Navajas D, Pedersen OF, Pellegrino R, Viegi G, Wanger J. Standardisation 331 of spirometry. Eur Respir J 2005 August;26(2):319-38.

332 14. Birnie D, thoe Schwartzenberg GW, Hop WC, van Essen-Zandvliet EE, Kerrebijn KF. 333 Does the outcome of the tidal breathing and dosimeter methods of assessing bronchial 334 responsiveness in children with asthma depend on age? Thorax 1990 335 March;45(3):199-202.

15. Merkus PJ, Stocks J, Beydon N, Lombardi E, Jones M, McKenzie SA, Kivastik J, 337 Arets BG, Stanojevic S. Reference ranges for interrupter resistance technique: the 338 Asthma UK Initiative. Eur Respir J 2010 July;36(1):157-63.

339 16. Stanojevic S, Wade A, Stocks J, Hankinson J, Coates AL, Pan H, Rosenthal M, Corey 340 M, Lebecque P, Cole TJ. Reference ranges for spirometry across all ages: a new 341 approach. Am J Respir Crit Care Med 2008 February 1;177(3):253-60.

342 17. Lombardi E, Sly PD, Concutelli G, Novembre E, Veneruso G, Frongia G, Bernardini 343 R, Vierucci A. Reference values of interrupter respiratory resistance in healthy 344 preschool white children. Thorax 2001 September;56(9):691-5.

345 18. McKenzie SA, Chan E, Dundas I, Bridge PD, Pao CS, Mylonopoulou M, Healy MJ. 346 Airway resistance measured by the interrupter technique: normative data for 2-10 year 347 olds of three ethnicities. Arch Dis Child 2002 September;87(3):248-51.

348 19. Merkus PJ, Arets HG, Joosten T, Siero A, Brouha M, Mijnsbergen JY, de Jongste JC, 349 van der Ent CK. Measurements of interrupter resistance: reference values for children $350 \quad 3-13$ yrs of age. Eur Respir J 2002 October;20(4):907-11. 
351 20. Oswald-Mammosser M, Llerena C, Speich JP, Donata L, Lonsdorfer. Measurements 352 of respiratory system resistance by the interrupter technique in healthy and asthmatic 353 children. Pediatr Pulmonol 1997 August;24(2):78-85.

354 21. Kannisto S, Vanninen E, Remes K, Korppi M. Interrupter technique for evaluation of 355 exercise-induced bronchospasm in children. Pediatr Pulmonol 1999 March;27(3):2033567

357 22. Davies PL, Doull IJ, Child F. The interrupter technique to assess airway 358 responsiveness in children with cystic fibrosis. Pediatr Pulmonol 2007 $359 \quad$ January;42(1):23-8.

360 23. Vink GR, Arets HG, van der LJ, van der Ent CK. Impulse oscillometry: a measure for 361 airway obstruction. Pediatr Pulmonol 2003 March;35(3):214-9.

362 24. Klug B, Bisgaard H. Specific airway resistance, interrupter resistance, and respiratory 363 impedance in healthy children aged 2-7 years. Pediatr Pulmonol 1998 May;25(5):32236431.

365 25. Bates JH, Sly PD, Kochi T, Martin JG. The effect of a proximal compliance on 366 interrupter measurements of resistance. Respir Physiol 1987 December;70(3):301-12.

367 26. Arets HG, van der Ent CK. Measurements of airway mechanics in spontaneously 368 breathing young children. Paediatr Respir Rev 2004 March;5(1):77-84.

369 27. Chan EY, Bridge PD, Dundas I, Pao CS, Healy MJ, McKenzie SA. Repeatability of 370 airway resistance measurements made using the interrupter technique. Thorax 2003 $371 \quad$ April;58(4):344-7. 


\section{FIGURE LEGENDS}

\section{4}

375 Figure 1. Mean changes from baseline of $\mathrm{FEV}_{\mathbf{1}}(\mathbf{1 A})$ and $\mathrm{R}_{\text {int }}(1 \mathrm{~B})$. At each dose step 376 patients are grouped according to whether (closed symbols) or not (open symbols) the $377 \mathbf{P D}_{20}$ endpoint $\left(20 \%\right.$ fall in $\left.\mathrm{FEV}_{1}\right)$ was reached at that dose step. Error bars represent 378 SEM.

380 Figure 2. Individual changes from baseline of $\mathbf{R}_{\text {int }}$ at each dose step, divided according to 381 whether (closed symbols) or not (open symbols) the $\mathrm{PD}_{20}$ endpoint (20\% fall in FEV $\mathrm{FV}_{1}$

382 was reached. At each dose step there is large overlap in changes from baseline of $\mathbf{R}_{\text {int }}$ 383 between both groups.

385 Figure 3. Receiver operator characteristic (ROC) curve showing the sensitivity and false 386 positive rate of the change from baseline of $\mathbf{R}_{\text {int }}$ as a measure to detect a $20 \%$ fall in $387 \quad \mathrm{FEV}_{\mathbf{1}}\left(\mathrm{PD}_{\mathbf{2 0}}\right)$. Area under the curve $(\mathrm{AUC})=\mathbf{0 . 6 5}$. 
Table 1: Baseline characteristics of children with moderate asthma $(n=73)$ who performed a methacholine provocation test with both $R_{\text {int }}$ and $F E V_{1}$ measurement at first visit.

\begin{tabular}{|c|c|c|}
\hline & & Median (interquartile range) \\
\hline \multicolumn{2}{|l|}{ Age (years) } & $9.2(7.6-10.6)$ \\
\hline \multicolumn{2}{|l|}{ Height $(\mathrm{cm})$} & $135.6(128.5-146.0)$ \\
\hline \multicolumn{2}{|c|}{ Sex (number $(\%)$ males) } & $43(58.9 \%)$ \\
\hline \multirow[t]{2}{*}{$\mathrm{FEV}_{1}^{\mathrm{a}}$} & z-score & $-0.26(-0.74-0.32)$ \\
\hline & $\%$ predicted & $96.8(90.8-104.2)$ \\
\hline \multirow[t]{2}{*}{$\mathrm{FVC}^{\mathrm{b}}$} & z-score & $0.10(-0.37-0.67)$ \\
\hline & $\%$ predicted & $101.4(95.7-108.3)$ \\
\hline \multirow[t]{2}{*}{$\mathrm{FEV}_{1} / \mathrm{FVC}$} & Z-score & $-0.81(-1.34--0.21)$ \\
\hline & $\%$ predicted & $94.1(89.7-98.6)$ \\
\hline \multirow[t]{2}{*}{$\mathrm{R}_{\text {int }}{ }^{\mathrm{c}}$} & z-score & $0.78(0.05-1.57)$ \\
\hline & $\%$ predicted & $123.4(107.0-147.2)$ \\
\hline
\end{tabular}

a) $\mathrm{FEV}_{1}=$ Forced expiratory volume in 1 second; b) $\mathrm{FVC}=$ Forced expiratory volume; c) $\mathbf{R}_{\text {int }}=$ Interrupter resistance. 
Table 2: Number of children with moderate asthma $(n=73)$ who reached the $\mathbf{P D}_{20}$ endpoint $^{\text {a) }}$ at subsequent methacholine dose steps.

\begin{tabular}{ccc}
\hline Dose step & Number \\
\hline $1=0.625 \mu \mathrm{g}$ & 0 \\
$3=1.25 \mu \mathrm{g}$ & 0 \\
$3=2.5 \mu \mathrm{g}$ & 2 \\
$4=5.0 \mu \mathrm{g}$ & 6 \\
$5=10.0 \mu \mathrm{g}$ & 10 \\
$6=20 \mu \mathrm{g}$ & 10 \\
$7=40 \mu \mathrm{g}$ & 10 \\
$8=80 \mu \mathrm{g}$ & 9 \\
$9=160 \mu \mathrm{g}$ & 5 \\
$10=320 \mu \mathrm{g}$ & 5 \\
No threshold & 21 \\
\hline
\end{tabular}

a) $\mathrm{PD}_{20}$ endpoint $=$ dose step at which a fall of more than $20 \%$ in $\mathrm{FEV}_{1}$ was reached. 
$1 \mathrm{~A}$

Figure 1. Mean changes from baseline of $\mathrm{FEV}_{1}(1 \mathrm{~A})$ and $\mathrm{R}_{\text {int }}(1 \mathrm{~B})$. At each dose step patients are grouped according to whether (closed symbols) or not (open symbols) the $\mathrm{PD}_{20}$ endpoint ( $20 \%$ fall in $\mathrm{FEV}_{1}$ ) was reached at that dose step. Error bars represent SEM.

$179 \times 190 \mathrm{~mm}$ (96 x 96 DPI)

John Wiley \& Sons, Inc. 
1B

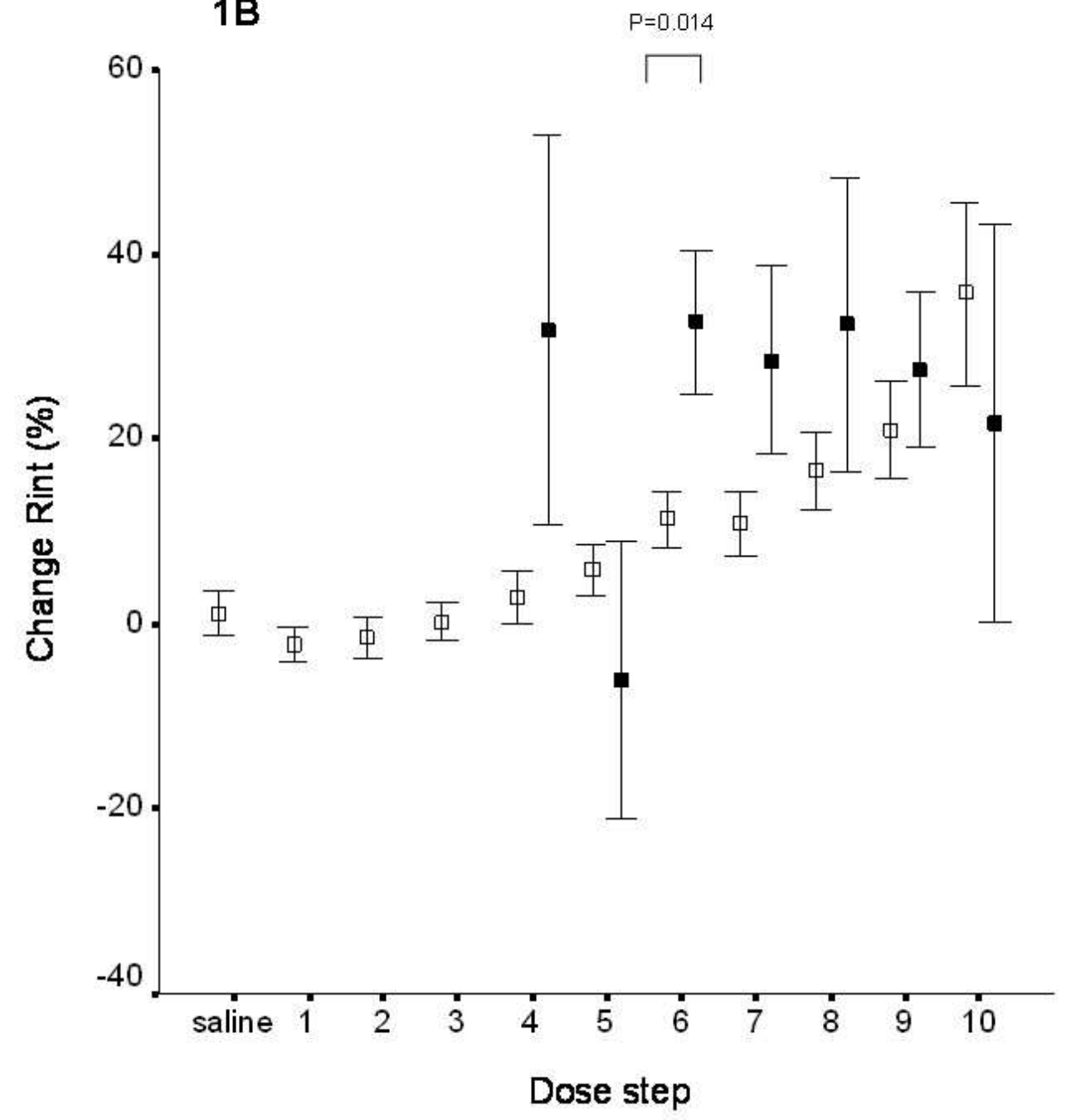

Figure 1. Mean changes from baseline of $\mathrm{FEV}_{1}(1 \mathrm{~A})$ and $\mathrm{R}_{\text {int }}(1 \mathrm{~B})$. At each dose step patients are grouped according to whether (closed symbols) or not (open symbols) the $\mathrm{PD}_{20}$ endpoint $(20 \%$ fall in $\mathrm{FEV}_{1}$ ) was reached at that dose step. Error bars represent SEM. $173 \times 190 \mathrm{~mm}(96 \times 96 \mathrm{DPI})$ 


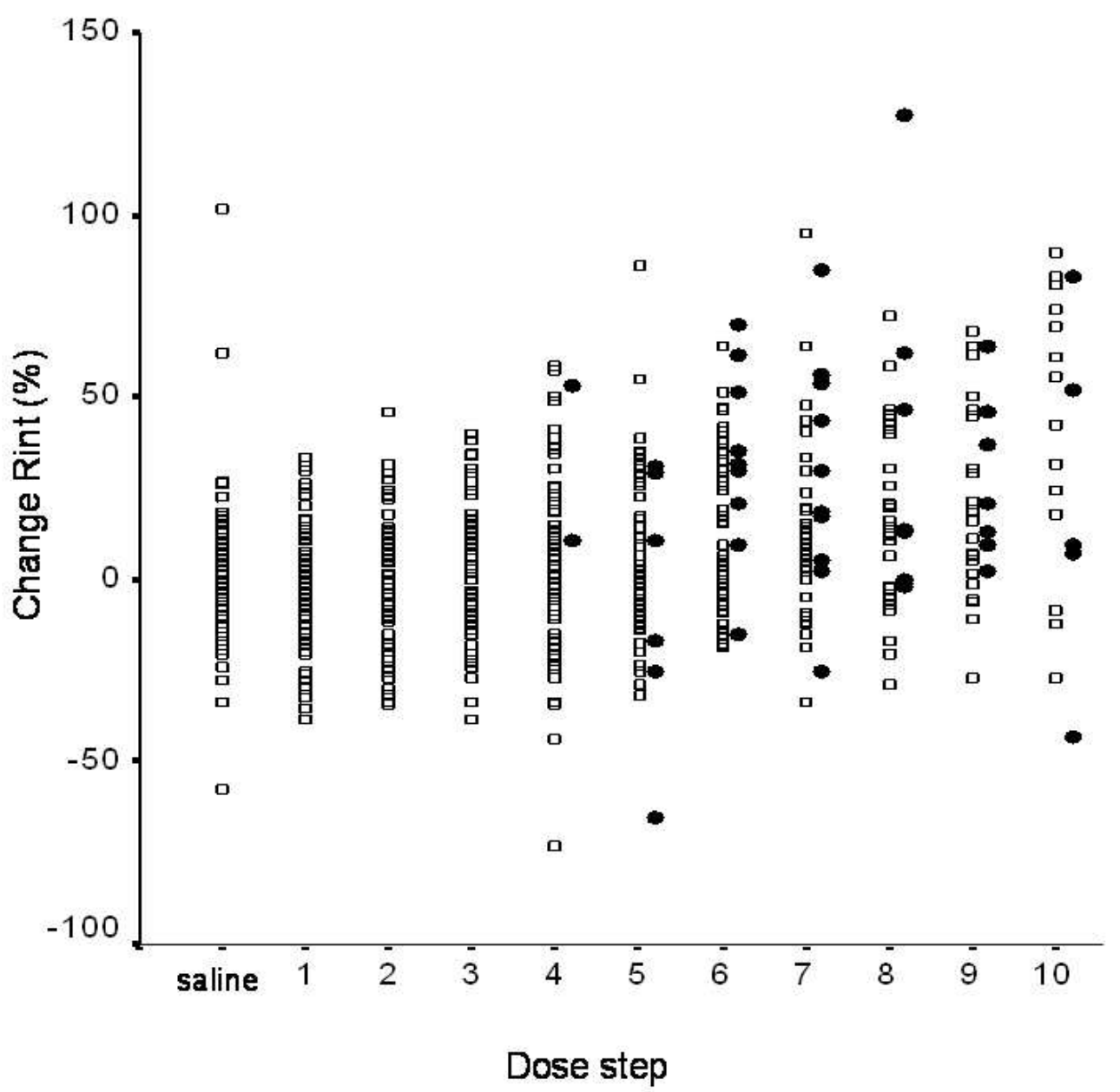

Figure 2. Individual changes from baseline of $R_{\text {int }}$ at each dose step, divided according to whether (closed symbols) or not (open symbols) the $\mathrm{PD}_{20}$ endpoint ( $20 \%$ fall in $\mathrm{FEV}_{1}$ ) was reached. At each dose step there is large overlap in changes from baseline of $\mathrm{R}_{\text {int }}$ between both groups. $191 \times 190 \mathrm{~mm}$ (96 x 96 DPI) 


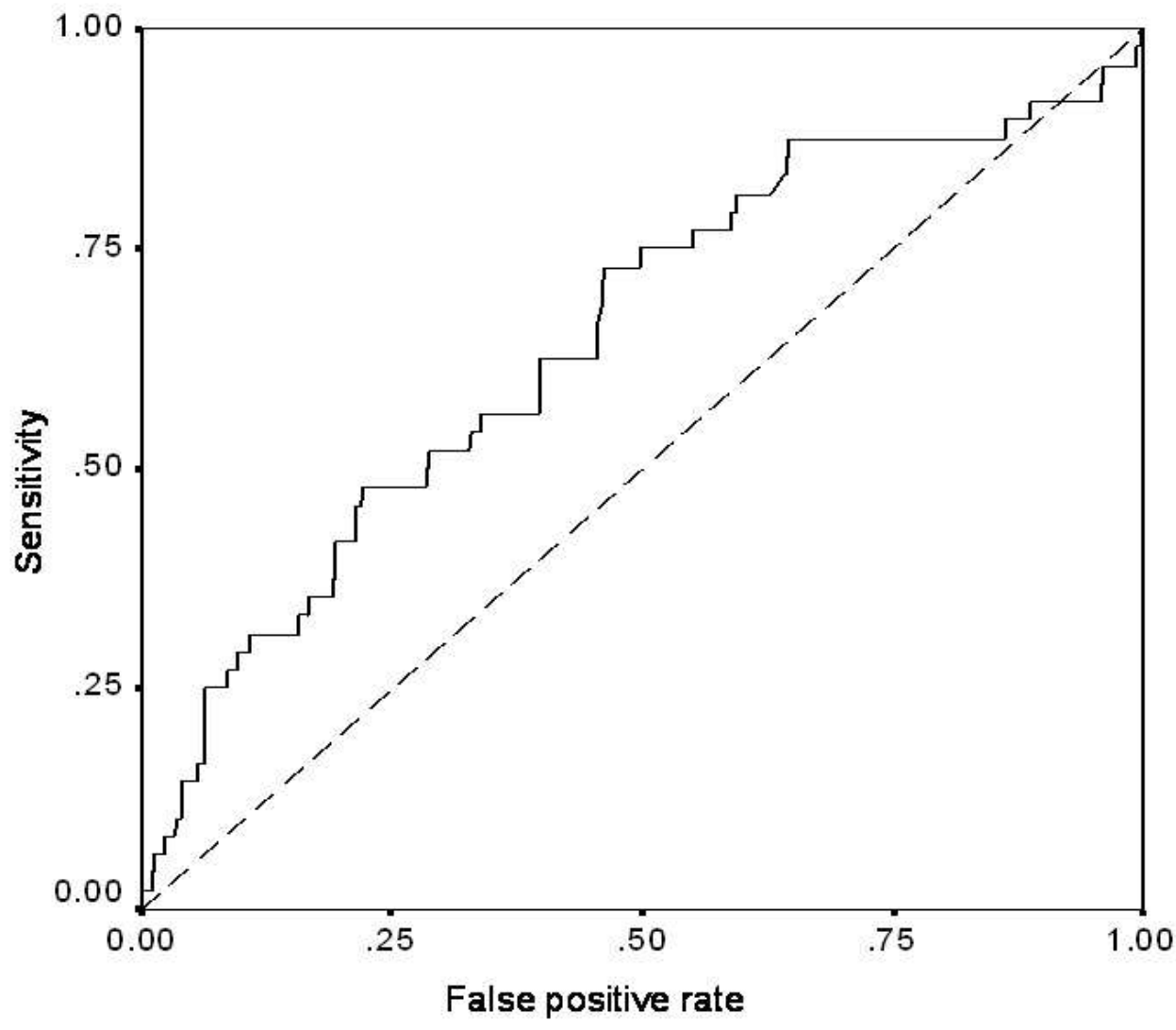

Figure 3. Receiver operator characteristic (ROC) curve showing the sensitivity and false positive rate of the change from baseline of $\mathrm{R}_{\text {int }}$ as a measure to detect a $20 \%$ fall in $\mathrm{FEV}_{1}\left(\mathrm{PD}_{20}\right)$. Area under the curve $(A \cup C)=0.65$. $186 \times 161 \mathrm{~mm}(96 \times 96 \mathrm{DPI})$ 


\section{ONLINE DATA SUPPLEMENT}

2

3 EVALUATION OF INTERRUPTER RESISTANCE IN METHACHOLINE CHALLENGE

4 TESTING IN CHILDREN

5

6 Authors: Marije Koopman, $\mathrm{MD}^{1}$; Hein J.L. Brackel, MD, $\mathrm{PhD}^{2}$; Anja A.P.H. Vaessen-

7 Verberne, $\mathrm{MD}, \mathrm{PhD}^{3}$; Wim C. Hop, $\mathrm{PhD}^{4}$; Cornelis K. van der Ent, $\mathrm{MD}, \mathrm{PhD}^{1}$; on behalf of

8 the COMBO-Rint research group.

9

10 Institutions:

11 1. Department of Paediatric Pulmonology, Wilhelmina Children's Hospital, University

12 Medical Centre Utrecht, Utrecht, the Netherlands.

13 2. Department of Paediatrics, Catharina Hospital, Eindhoven, the Netherlands.

14 3. Department of Paediatrics, Amphia Hospital, Breda, the Netherlands

15 4. Department of Biostatistics, Erasmus MC - University Medical

16 Centre Rotterdam, Rotterdam, the Netherlands

17

18 COMBO-Rint research group consists of: H.G.M. Arets, N.J. van den Berg, P.L.P. Brand,

19 E.J. Duiverman, H.J. Hendriks, J.W.C.M. Heynens, J.C. van Nierop, M. Nuysink.

21 Financial support: This study was supported by an unconditional grant from

22 GlaxoSmithKline Pharma Europe. 


\section{MATERIALS AND METHODS}

24 This study was a substudy performed in some centres participating in the multicentre COMBO-study. The COMBO-study is a blinded study comparing the clinical effects of

fluticasone propionate $200 \mathrm{mcg}$ BD versus salmeterol/fluticasone propionate 50/100 mcg BD on number of symptoms free days in children between 6 and 16 years of age (trial registration number NCT00197106; GSK study number SAM101667) (1). It was performed in 158 patients in 19 hospitals in the Netherlands, between June 2005 and October 2008. All children if $\geq 12$ years old) before the start of the study.

\section{Measurements}

\section{Methacholine challenge testing}

Methacholine challenge tests were performed using the dosimeter method $(3 ; 4)$ with a nebulizer (model 646, DeVilbiss Healthcare, Somerset, USA) attached to a dosimeter (Rosenthal French dosimeter, PDS Instrumentation, Louisville CO, USA). After baseline $\mathrm{R}_{\text {int }}$ and $\mathrm{FEV}_{1}$ measurements, $0.9 \% \mathrm{NaCl}$ was inhaled to rule out non-specific reactions and additionally methacholine chloride was administered in doubling doses $(0.625 \mu \mathrm{g}, 1.25 \mu \mathrm{g}$, $2.5 \mu \mathrm{g}, 5.0 \mu \mathrm{g}, 10.0 \mu \mathrm{g}, 20.0 \mu \mathrm{g}, 40.0 \mu \mathrm{g}, 80 \mu \mathrm{g}, 160 \mu \mathrm{g}, 320 \mu \mathrm{g})$. The procedure was performed according to the latest ATS/ERS guidelines (4) as follows: after manually triggering of the dosimeter children were instructed to inhale slowly from forced residual 
capacity (FRC) to total lung capacity (TLC) and then hold their breath for 2 seconds. Two minutes after each inhalation, $\mathrm{R}_{\mathrm{int}}$ and $\mathrm{FEV}_{1}$ were measured. Provocation was continued after at least five minutes and until the $\mathrm{PD}_{20}$ or the maximum dose was reached.

\section{Interrupter resistance}

Airway resistance measurements were carried out using the MicroRint (Micro Medical

Limited, Kent, UK) that contains a pneumotachometer, a flow interruption valve and a pressure transducer to measure mouth pressure post-occlusion. A bacterial filter was used (Spirosafe bacterial filter, Micro Medical, Kent, UK). Measurements were performed conform the latest ATS/ERS guideline (5). The child was seated and diverted to ensure quiet tidal breathing. Children were breathing through a mouth piece while the technicians supported the cheeks to reduce the change in upper airway compliance. Ten interruptions of $100 \mathrm{~ms}$ were made at peak expiratory flow with a random frequency, with the valve closing within $10 \mathrm{~ms}$. The MicroRint software automatically rejected measurements that showed an artefact on the pressure curve. Additionally measurements that showed tachypnoea or irregular breathing, vocalisation, or hyperextension or flexion of the neck were manually discarded as well as were tracings with a horizontal or declining pressure signal suggesting air leakage around the mouthpiece. $\mathrm{R}_{\text {int }}$ values were calculated using the two-point linear fit back extrapolation technique to $t=15 \mathrm{~ms}$ (6). A minimum of five successful interruptions was required to calculate the median $R_{\text {int }}$ value. Reference values of Merkus et al. (7) were used to convert $R_{\text {int }}$ outcomes into percentage predicted values.

\section{Spirometry}

Maximal expiratory flow-volume measurements were performed with standardized equipment. Seven centres used a Jaeger pneumotachometer (Viasys Healthcare, Hochberg, 
73 Germany), 1 centre used the Microloop (Micro Medical, Kent, UK) and 1 centre used a Zan

74 spirometer (nSpire Health GmbH, Oberthulba, Germany). Measurements were performed

75 according to the latest ATS/ERS guidelines (8) with the child sitting and wearing a nose clip,

76 without using a bacterial filter. Equipment calibration was performed daily and all

77 measurements were BTPS corrected. After a full inspiration children performed a maximally

78 forced and full expiration. At least three technician-accepted flow-volume curves were

79 obtained and the largest $\mathrm{FEV}_{1}$ was selected. Reference values of Stanojevic (9) were used.

80

Analysis; Calculation of intrapatient coefficients of variation (CV):

To quantify the variability of $\mathrm{FEV}_{1}$ and $\mathrm{R}_{\text {int }}$ measurements between the various dose steps

during the methacholine provocation test, a coefficient of variation $(\mathrm{CV})$ was calculated for

each separate patient. This was done by fitting smooth third degree polynomials of each parameter separately versus log-methacholine dose for each individual patient to allow a gradual change over the subsequent dose steps. The resulting standard deviation of residuals individual $\mathrm{CV}$ of the measurements. The resulting individual paired CV's of $\mathrm{FEV}_{1}$ and $\mathrm{R}_{\text {int }}$ were compared using Wilcoxon's test.

\section{RESULTS}

92 Visual inspection of individual $\mathrm{R}_{\text {int }}$ profiles during the challenge test showed large

93 fluctuations with rises and falls at subsequent dose steps. In contrast, much smoother profiles 94 with gradual falls were found for $\mathrm{FEV}_{1}$ (E-figure 1). 
96

97

98

99

100

101

102

103

104

105

106

107

108

109

110

111

112

113

114

115

116

117

\section{E-REFERENCES}

E1. Vaessen-Verberne A.A.P.H., Berg van den N.J., Nierop van J.C., Brackel H.J.L., Gerrits G.P.J.M., Hop W.C.J., Duiverman E.J. Combination therapy salmeterol/fluticasone versus doubling dose of fluticasone in children with asthma. Am.J.Respir.Crit Care Med. Accepted for publication. 2010.

E2. Expert Panel Report 3 (EPR-3): Guidelines for the Diagnosis and Management of Asthma-Summary Report 2007. J Allergy Clin Immunol 2007 November;120(5 Suppl):S94-138.

E3. Birnie D, thoe Schwartzenberg GW, Hop WC, van Essen-Zandvliet EE, Kerrebijn KF. Does the outcome of the tidal breathing and dosimeter methods of assessing bronchial responsiveness in children with asthma depend on age? Thorax 1990 March;45(3):199-202.

E4. Crapo RO, Casaburi R, Coates AL, Enright PL, Hankinson JL, Irvin CG, MacIntyre NR, McKay RT, Wanger JS, Anderson SD, Cockcroft DW, Fish JE, Sterk PJ. Guidelines for methacholine and exercise challenge testing-1999. This official statement of the American Thoracic Society was adopted by the ATS Board of Directors, July 1999. Am J Respir Crit Care Med 2000 January;161(1):309-29.

E5. Beydon N, Davis SD, Lombardi E, Allen JL, Arets HG, Aurora P, Bisgaard H, Davis GM, Ducharme FM, Eigen H, Gappa M, Gaultier C, Gustafsson PM, Hall GL, Hantos Z, Healy MJ, Jones MH, Klug B, Lodrup Carlsen KC, McKenzie SA, Marchal F, Mayer OH, Merkus PJ, Morris MG, Oostveen E et al. An official American Thoracic 
118 Society/European Respiratory Society statement: pulmonary function testing in 119 preschool children. Am J Respir Crit Care Med 2007 June 15;175(12):1304-45.

120 E6. Phagoo SB, Wilson NM, Silverman M. Evaluation of the interrupter technique for 121 measuring change in airway resistance in 5-year-old asthmatic children. Pediatr 122 Pulmonol 1995 December;20(6):387-95.

123 E7. Merkus PJ, Stocks J, Beydon N, Lombardi E, Jones M, McKenzie SA, Kivastik J, 124 Arets BG, Stanojevic S. Reference ranges for interrupter resistance technique: the 125 asthma UK initiative. Eur Respir J 2010 July;36(1):157-63.

126 E8. Miller MR, Hankinson J, Brusasco V, Burgos F, Casaburi R, Coates A, Crapo R, 127 Enright P, van der Grinten CP, Gustafsson P, Jensen R, Johnson DC, MacIntyre N, 128 McKay R, Navajas D, Pedersen OF, Pellegrino R, Viegi G, Wanger J. Standardisation 129 of spirometry. Eur Respir J 2005 August;26(2):319-38.

130 E9. Stanojevic S, Wade A, Stocks J, Hankinson J, Coates AL, Pan H, Rosenthal M, Corey 131 M, Lebecque P, Cole TJ. Reference ranges for spirometry across all ages: a new 132 approach. Am J Respir Crit Care Med 2008 February 1;177(3):253-60. 


\section{E-FIGURE LEGEND}

136 E-figure 1. Individual fluctuations of absolute values of $\operatorname{FEV}_{1}(\mathrm{E} 1 \mathrm{~A})$ and $\mathbf{R}_{\text {int }}(\mathrm{E} 1 \mathrm{~B})$

137 plotted against dose steps of methacholine in 73 children with moderate asthma. Dose 138 step 0.5 denotes Saline.

139

140 


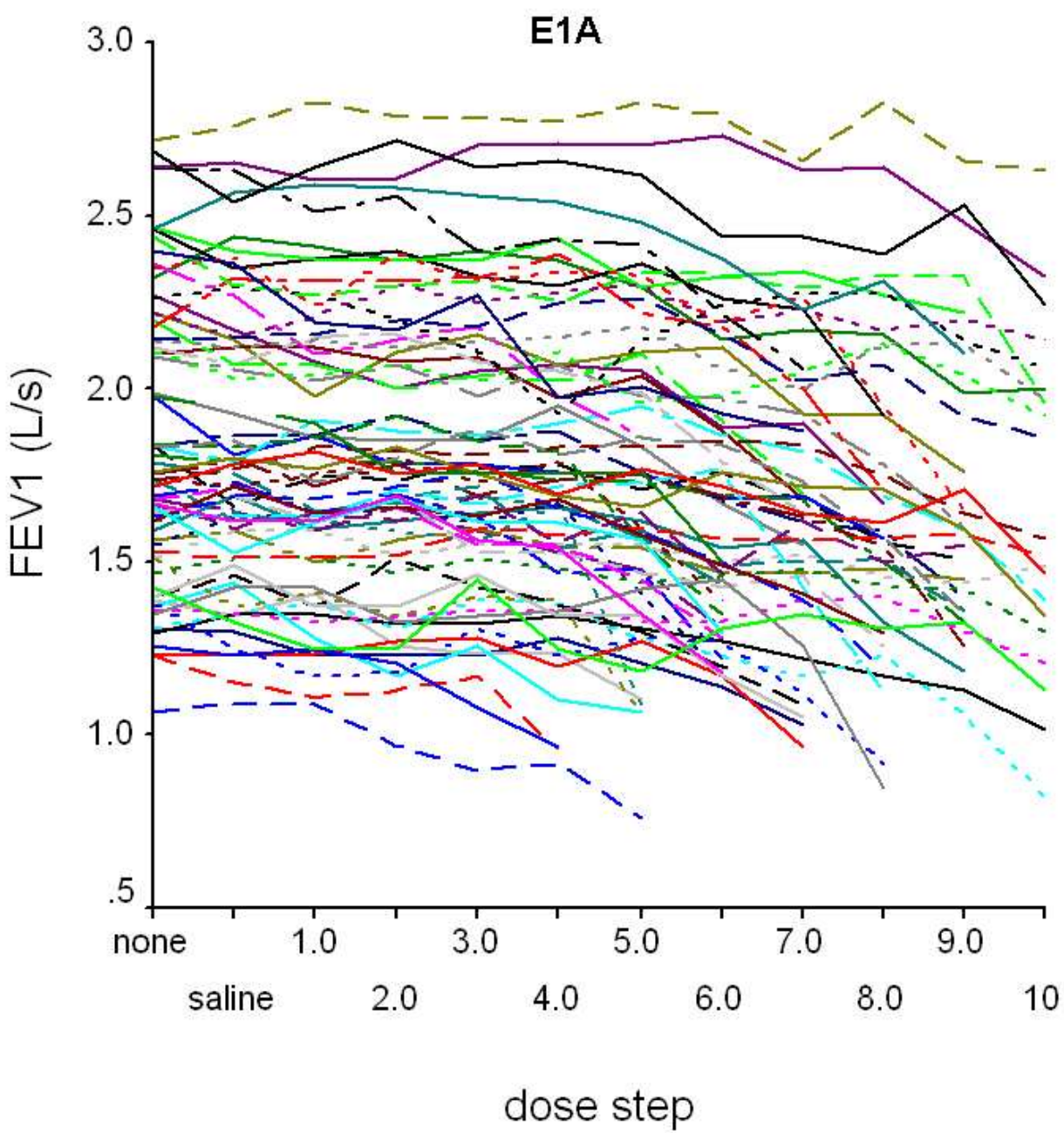

E-figure 1. Individual fluctuations of absolute values of FEV $1(E 1 A)$ and $R_{\text {int }}(E 1 B)$ plotted against dose steps of methacholine in 73 children with moderate asthma. Dose step 0.5 denotes Saline. $190 \times 196 \mathrm{~mm}(96 \times 96 \mathrm{DPI})$

John Wiley \& Sons, Inc. 


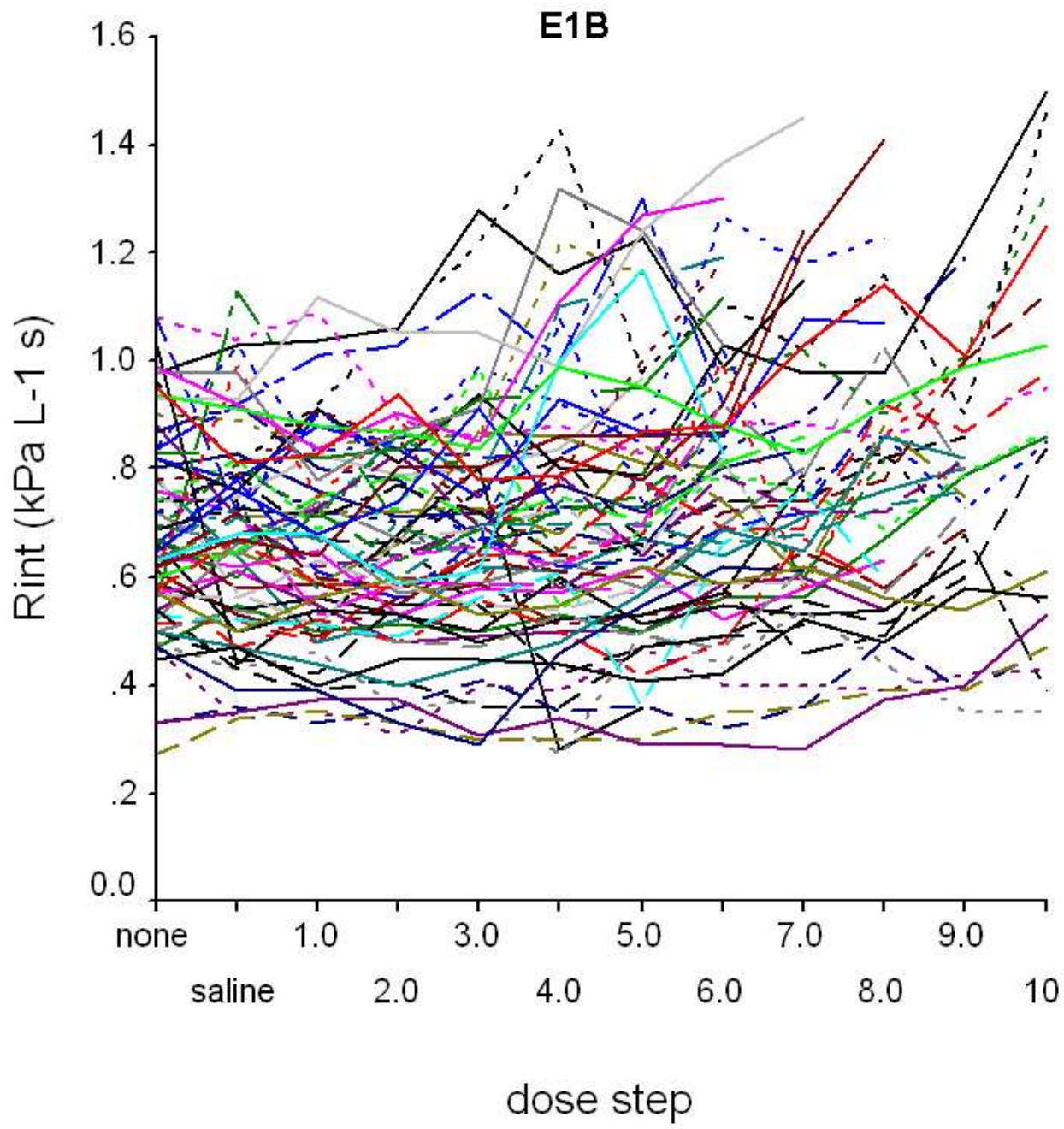

E-figure 1. Individual fluctuations of absolute values of $F E V_{1}(E 1 A)$ and $R_{\text {int }}(E 1 B)$ plotted against dose steps of methacholine in 73 children with moderate asthma. Dose step 0.5 denotes Saline. $190 \times 199 \mathrm{~mm}(96 \times 96$ DPI) 
1 Title: Evaluation of interrupter resistance in methacholine challenge testing in children

2

3 Authors: Marije Koopman, $\mathrm{MD}^{1}$; Hein J.L. Brackel, MD, $\mathrm{PhD}^{2}$; Anja A.P.H. Vaessen-

4 Verberne, $\mathrm{MD}, \mathrm{PhD}^{3}$; Wim C. Hop, $\mathrm{PhD}^{4}$; Cornelis K. van der Ent, $\mathrm{MD}, \mathrm{PhD}^{1}$; on behalf of 5 the COMBO-Rint research group.

6

7 Institutions:

8 1. Department of Paediatric Pulmonology, Wilhelmina Children's Hospital, University

9 Medical Centre Utrecht, Utrecht, the Netherlands.

10 2. Department of Paediatrics, Catharina Hospital, Eindhoven, the Netherlands.

11 3. Department of Paediatrics, Amphia Hospital, Breda, the Netherlands

12 4. Department of Biostatistics, Erasmus MC - University Medical

13 Centre Rotterdam, Rotterdam, the Netherlands

14

15 COMBO-Rint research group consists of: H.G.M. Arets, N.J. van den Berg, P.L.P. Brand,

16 E.J. Duiverman, H.J. Hendriks, J.W.C.M. Heynens, J.C. van Nierop, M. Nuysink.

17

18 Corresponding author

19 Ms. Marije Koopman

20 Wilhelmina Children's Hospital/University Medical Centre Utrecht

21 Department of Paediatric Pulmonology, Huispostnummer KH.01.419.0

22 P O Box 85090, 3508 AB Utrecht, the Netherlands

23 Email: M.Koopman-5@umcutrecht.nl

24 Telephone number: 0031-88-7553201 / Fax number: 0031-88-7554747

25 
26 Word count body of manuscript: 2483

27

28 Financial support: This study was supported by an unconditional grant from

29 GlaxoSmithKline Pharma Europe.

30

31 This article has supplementary material.

32

33 Running head: $\mathrm{R}_{\text {int }}$ in bronchial challenge testing 
34

35

36

\section{SUMMARY}

Bronchial hyperresponsiveness is a key feature of asthma and is assessed using bronchial provocation tests. The primary outcome in such tests (a 20\% decrease in forced expiratory volume in 1 second $\left.\left(\mathrm{FEV}_{1}\right)\right)$ is difficult to measure in young patients. This study evaluated the sensitivity and specificity of the interrupter resistance $\left(\mathrm{R}_{\text {int }}\right)$ technique, which does not require active patient participation, by comparing it to the primary outcome measure.

Methacholine challenge tests were performed in children with a history of moderate asthma and bronchial hyperresponsiveness. Mean and individual changes in $\mathrm{R}_{\text {int }}$ and $\mathrm{FEV}_{1}$ were studied. A receiver operating characteristic (ROC) curve was used to describe sensitivity and specificity of $\mathrm{R}_{\text {int }}$.

Seventy-three children (median age: 9.2 yrs; range: 6.3- 13.4 yrs) participated. There was a significant $(\mathrm{p}<0.01)$ increase in mean $\mathrm{R}_{\mathrm{int}}$ with increasing methacholine doses.

However, individual changes of $\mathrm{R}_{\mathrm{int}}$ showed large fluctuations. There was great overlap in change of $\mathrm{R}_{\text {int }}$ between children who did and did not reach the $\mathrm{FEV}_{1}$ endpoint. A ROC-curve showed an area under the curve of 0.65 .

Because of low sensitivity and specificity, the use of $\mathrm{R}_{\text {int }}$ to diagnose bronchial hyperresponsiveness in individual patients seems limited.

\section{Word count abstract: 190}

Key words: Bronchial hyperresponsiveness, bronchial provocation test, forced expiratory volume in 1 second, interrupter resistance, methacholine challenge test, sensitivity, specificity. 


\section{INTRODUCTION}

60 According to GINA guidelines bronchial hyperresponsiveness (BHR) is a key feature of 61 asthma (1). To objectify BHR, forced flow volume manoeuvres are required to measure the 62 forced expiratory volume in one second $\left(\mathrm{FEV}_{1}\right)$, as primary outcome measure in bronchial 63 challenge testing (2). Because of the difficulty of obtaining forced lung function

64 measurements in early childhood the diagnosis of asthma in this age group is challenging and 65 complicated. Several studies have advocated measurement of the interrupter resistance $\left(\mathrm{R}_{\mathrm{int}}\right)$ 66 as an alternative to quantify airway obstruction in preschool children and in children with 67 developmental delay $(3 ; 4)$. The interrupter technique is non-invasive and can be obtained 68 during tidal breathing (5). $\mathrm{R}_{\text {int }}$ can be measured in children from two years of age as it 69 requires minimal cooperation (6). The $\mathrm{R}_{\text {int }}$ technique has been compared to body 70 plethysmography (7) and transcutaneous partial pressure of oxygen measurements (7-10) 71 during methacholine challenge tests, but most studies made no comparison with the outcome 72 measure $\mathrm{FEV}_{1}$. The one study that compared $\mathrm{R}_{\text {int }}$ with $\mathrm{FEV}_{1}$ during methacholine challenge 73 testing reported a mean increase in $\mathrm{R}_{\text {int }}$ with increasing doses of methacholine (11). However, 74 this study did not present the changes in $\mathrm{R}_{\mathrm{int}}$ for individual patients nor how these related to 75 individual changes in $\mathrm{FEV}_{1}$. The ability of $\mathrm{R}_{\mathrm{int}}$ to detect methacholine induced 76 bronchoconstriction in individual patients, as measured by a $20 \%$ decrease in $\mathrm{FEV}_{1}$, has never 77 been studied.

The latest ATS/ERS statement on pulmonary function testing in preschool children 79 recommended the need to determine the role of $\mathrm{R}_{\text {int }}$ in bronchial challenge tests (5). The 80 current study evaluated the sensitivity and specificity of $\mathrm{R}_{\text {int }}$ to detect airflow obstruction 81 during methacholine challenge tests in asthmatic children by comparing measurements with $82 \quad \mathrm{FEV}_{1}$ as the gold standard. 


\section{MATERIALS AND METHODS}

84

This study was a substudy of the multicentre COMBO-study in children between 6 and 16 years with moderate asthma (see online supplement) (12). Nine out of 19 hospitals performed additional $\mathrm{R}_{\text {int }}$ measurements during methacholine challenge tests. The children from these centres were included in this substudy. It was approved by the local medical ethical committees and written informed consent was obtained from the parents (and the child if $\geq 12$ years) before start of the study. For additional information see online supplement.

\section{Study protocol}

Methacholine provocation tests were performed twice (at start of study and after 26 weeks) measuring $\mathrm{R}_{\text {int }}$ and $\mathrm{FEV}_{1}$ after each methacholine dose. All children abstained from longacting $\beta 2$ agonists and inhaled steroids for 12 hours before the first methacholine provocation test (and 36 hours before the second methacholine provocation test), and from short acting $\beta 2$ agonists for 6 hours before provocation testing. To prevent possible, unwanted physiologic effects of deep inhalation on $\mathrm{R}_{\mathrm{int}}, \mathrm{R}_{\mathrm{int}}$ was measured prior to $\mathrm{FEV}_{1}$. Pulmonary function tests were performed to conform with latest ATS/ERS guidelines $(2 ; 5 ; 13)$ and briefly described below. The complete methodology is described in the online supplement.

\section{Methacholine challenge testing}

Methacholine challenge tests were performed using the dosimeter method $(2 ; 14)$ with a nebulizer (model 646, DeVilbiss Healthcare, Somerset, USA) attached to a dosimeter (Rosenthal French dosimeter, PDS Instrumentation, Louisville CO, USA). Methacholine chloride was administered in doubling doses and provocation was continued after at least five minutes and until the dose at which at least $20 \%$ fall in $\mathrm{FEV}_{1}\left(\mathrm{PD}_{20}\right)$ or the maximum dose was reached. 
Interrupter resistance

110 Airway resistance measurements were carried out using the MicroRint (Micro Medical

111 Limited, Kent, UK). A bacterial filter was used (Spirosafe bacterial filter, Micro Medical,

112 Kent, UK). Reference values of Merkus et al. (15) were used.

114 Spirometry

115 Maximal expiratory flow-volume measurements were performed with standardized

116 equipment, using reference values of Stanojevic (16).

118 Analysis

119 Changes in $\mathrm{FEV}_{1}$ and $\mathrm{R}_{\text {int }}$ were analyzed as percentages change from baseline. Change in $\mathrm{R}_{\text {int }}$ 120 was also assessed as change in percentage predicted and change in z-score, computed from

121 the latest $\mathrm{R}_{\text {int }}$ reference values (15). Wilcoxon Signed Ranks test was used to investigate

122 whether there was a significant increase in mean change from baseline of $\mathrm{R}_{\text {int }}$ at each dose

123 step. To quantify the variability of $\mathrm{FEV}_{1}$ and $\mathrm{R}_{\text {int }}$ within individuals between the various

124 dosesteps, coefficients of variation (CV) were calculated (see online supplement for

125 calculation). The resulting individual paired CV's of $\mathrm{FEV}_{1}$ and $\mathrm{R}_{\mathrm{int}}$ were compared using

126 Wilcoxon's test. Comparison of mean CV's between centers was done using the Kruskal-

127 Wallis test. The association between changes in $\mathrm{FEV}_{1}$ and changes in $\mathrm{R}_{\text {int }}$ at $\mathrm{PD}_{20}$ was

128 analysed using Spearman's correlation $\left(\mathrm{r}_{\mathrm{S}}\right)$. At each separate dose step Mann Whitney tests

129 were computed to compare the difference in changes from baseline between subjects who did

130 and who did not reach the $\mathrm{PD}_{20}$ endpoint at the dose step. Cox regression, with change from

131 baseline of $\mathrm{R}_{\text {int }}$ as time-dependent variable, was used to analyse whether these changes were

132 predictive for having reached the $\mathrm{PD}_{20}$ endpoint at the subsequent dose steps. The sensitivity 
1

3

4

5

6

7

8

133 and specificity of $\mathrm{R}_{\mathrm{int}}$ in relation to having reached $\mathrm{FEV}_{1}$-based $\mathrm{PD}_{20}$ was described by

134 receiver operating characteristic (ROC) curves. The area under the curve (AUC) shows

135 whether the change in $\mathrm{R}_{\text {int }}$ can correctly classify those who do and do not reach the $\mathrm{PD}_{20}$

136 endpoint. We used the coefficient of repeatability calculated by Beydon et al. (a 32.1\%

137 increase in $R_{\text {int }}$ ) as a cut-off value to calculate the sensitivity and specificity of $R_{\text {int }}$ to predict a $13820 \%$ fall in $\mathrm{FEV}_{1}$.

139

140

141 


\section{RESULTS}

143 At the first COMBO-study visit 73 children with moderate asthma (60\% boys) with a median

144 age of 9.2 years (range: 6.3 - 13.4 years) performed both $R_{\text {int }}$ and $F E V_{1}$ measurements during

145 methacholine challenge. Baseline characteristics are shown in Table 1. Fifty-two children

146 reached the $\mathrm{PD}_{20}$ endpoint and were defined as responders (Table 2).

147 There was a significant increase from baseline of $R_{\text {int }}$ starting at the sixth methacholine

148 dose step and all dose steps thereafter (all $\mathrm{p}<0.01$ ). From the first dose step mean $\mathrm{FEV}_{1}$ was

149 significantly different from baseline value (all $\mathrm{p}<0.01$ ), except for dose step 2 . Visual

150 inspection of individual $\mathrm{R}_{\text {int }}$ profiles during the challenge test showed large fluctuations with

151 rises and falls at subsequent dose steps. In contrast, much smoother profiles with gradual falls

152 were found for $\mathrm{FEV}_{1}$ (see E-figure 1 in the online supplement). To express the variability in

153 individual curves, the $\mathrm{CV}$ of measured values was calculated per patient. For $\mathrm{R}_{\text {int }}$ the mean

$154 \mathrm{CV}$ of all patients was $10.6 \%\left(10^{\text {th }}-90^{\text {th }}\right.$ percentile: $\left.5.5 \%-16.3 \%\right)$. The mean CV for FEV 1

155 was significantly smaller: $2.9 \%(1.7 \%-4.3 \%, \mathrm{p}<0.001)$. Further analysis of CV $\mathrm{R}_{\text {int }}$ showed

156 that there was no correlation with age $\left(r_{S}=-0.13, p=0.26\right)$. Also centres did not significantly

157 differ from each other (Kruskal-Wallis test: $\mathrm{p}=0.17$ ).

158 Analysing the 52 children who reached the $\mathrm{PD}_{20}$ endpoint, there was no significant

159 correlation between changes from baseline of $\mathrm{FEV}_{1}$ and changes from baseline of $\mathrm{R}_{\mathrm{int}}$ at the

160 last dose step at which the $\mathrm{PD}_{20}$ endpoint was reached $\left(\mathrm{r}_{\mathrm{S}}=0.11, \mathrm{p}=0.44\right)$.

161 Figure 1 demonstrates the mean changes from baseline of $\mathrm{FEV}_{1}$ and $\mathrm{R}_{\text {int }}$ at each dose

162 step, while at each dose step patients are grouped according to whether or not the $\mathrm{PD}_{20}$

163 endpoint was reached at the dose step. At none of the dose steps there was a significant

164 difference in the mean change of $\mathrm{R}_{\mathrm{int}}$ from baseline between those who reached the $\mathrm{PD}_{20}$

165 endpoint at that dose step versus those who did not, except at dose step 6 ( $\mathrm{p}=0.014$ ) (figure

166 1B). A combined analysis of all dose steps comparing responders and non-responders, using 
167 Cox regression analysis, showed that a greater change of $\mathrm{R}_{\mathrm{int}}$ was associated with a higher

168 probability of reaching the $\mathrm{PD}_{20}$ endpoint $(\mathrm{p}=0.038)$. However, when inspecting the

169 individual changes from baseline, there is large overlap of children who did and who did not

170 reach the $\mathrm{PD}_{20}$ endpoint at the various dose steps (Figure 2). A ROC curve of changes from

171 baseline of $\mathrm{R}_{\text {int }}$ as a measure to detect a $20 \%$ decrease in $\mathrm{FEV}_{1}$ is shown in Figure 3, resulting

172 in a small AUC of 0.65.

173 When using a $32.1 \%$ increase in $\mathrm{R}_{\text {int }}$ as cut-off value to calculate the sensitivity and

174 specificity of $\mathrm{R}_{\mathrm{int}}$ to predict a $20 \%$ fall in $\mathrm{FEV}_{1}$, we found a sensitivity of $50 \%$ and a

175 specificity of $43 \%$. This means that $\mathrm{R}_{\mathrm{int}}$ was able to detect half of the responders as

176 determined by PD20 and that in 12 out of 21 children $\mathrm{R}_{\text {int }}$ increased with more than $32 \%$

177 without a concomitant fall of $\mathrm{FEV}_{1}$ with $20 \%$.

178 Repeating all analyses with change in $\mathrm{R}_{\text {int }}$ expressed as change in percentage predicted

179 and change in z-score led to similar results (data not shown). AUC's of ROC curves for

180 change in percentage predicted and for change in z-score were both 0.66.

181 In 64 children the methacholine challenge test was repeated after 26 weeks. The

182 analyses to compare $\mathrm{R}_{\text {int }}$ with $\mathrm{FEV}_{1}$ (as described above) showed similar results (data not

183 shown). The AUC of the ROC curve was 0.61.

184

185 
186

187

188

189

190

191

192

193

194

195

196

197

198

199

200

201

202

203

204

205

206

207

208

209

210

\section{DISCUSSION}

This study showed that, although there was a significant increase of mean $\mathrm{R}_{\text {int }}$ values with higher doses of methacholine, individual changes in $\mathrm{R}_{\text {int }}$ are highly variable during

methacholine challenge. The sensitivity and specificity of $\mathrm{R}_{\text {int }}$ to detect methacholine induced bronchoconstriction is low, which might limit the use of $\mathrm{R}_{\mathrm{int}}$ in individual patients.

Several studies evaluated lung function measures requiring less patient effort than $\mathrm{FEV}_{1}$, which could possibly be used as alternative measures of changes in bronchoconstriction. Klug et al showed that $R_{\text {int }}$ was significantly less sensitive than specific airway resistance in detecting changes in airway function (7). Phagoo et al found that $R_{\text {int }}$ was also less sensitive and showed more variability than transcutaneous partial pressure of oxygen measurements $(9 ; 10)$. In a study of Beydon et al. the majority of children with a $20 \%$ fall in transcutaneous partial pressure of oxygen $\left(\mathrm{PD}_{20} \mathrm{P}_{t c} \mathrm{O}_{2}\right)$ showed a significant change of $\mathrm{R}_{\text {int }}$ during methacholine challenge. However, all children who did not reach the $\mathrm{PD}_{20} \mathrm{P}_{\mathrm{tc}} \mathrm{O}_{2}$ had at least once a significant change from baseline (8), resulting in many false positive as well as false negative outcomes.

Despite these data $\mathrm{R}_{\text {int }}$ is still advocated as an alternative measure for airway obstruction in those who are not able to perform forced breathing manoeuvres. Several studies showed significant correlation between gold standard $\mathrm{FEV}_{1}$ and $\mathrm{R}_{\mathrm{int}}$ in groups of patients $(4 ; 6)$, and reference values for $\mathrm{R}_{\mathrm{int}}$ measurement in healthy controls have been published (15;17-20). Although there is convincing evidence on the value of $R_{\text {int }}$ measurement as a measure of airway obstruction in groups of patients, the sensitivity of $\mathrm{R}_{\mathrm{int}}$ to detect changes in airway obstruction in individual patients has been little researched. Only one previous study compared $\mathrm{R}_{\text {int }}$ with $\mathrm{FEV}_{1}$ during methacholine challenge testing (11) and found that on average $\mathrm{R}_{\text {int }}$ increased during methacholine challenge comparable to changes in $\mathrm{FEV}_{1}$ measurements, but individual changes in $\mathrm{R}_{\text {int }}$ were not shown. Kannisto et al. compared $\mathrm{R}_{\text {int }}$ 
211 with $\mathrm{FEV}_{1}$ during exercise challenge to diagnose BHR (21). However, in this study only 11 $212(22 \%)$ children reached the $\mathrm{R}_{\text {int }}$ endpoint (15\% increase from baseline) and only 6 of them 213 also reached the $\mathrm{FEV}_{1}$ endpoint (10\% decrease from baseline). The children who showed a $21415 \%$ rise in $R_{\text {int }}$ but who did not have a $10 \%$ decrease in $\mathrm{FEV}_{1}$ could be misclassified by $\mathrm{R}_{\text {int }}$ 215 as having BHR. Davies et al. investigated the correlation between $R_{\text {int }}$ and $F E V_{1}$ in 216 bronchodilator response, and despite a correlation between $\mathrm{FEV}_{1}$ and $\mathrm{R}_{\mathrm{int}}$ in a group of 217 patients, they found no significant correlation in individual children (22).

218 To evaluate the sensitivity and specificity of the $\mathrm{R}_{\mathrm{int}}$ technique to detect changes in 219 airway obstruction in individual children we performed simultaneous measurements of $\mathrm{R}_{\mathrm{int}}$ 220 and gold standard $\mathrm{FEV}_{1}$ in a large group of children with asthma. We show that in individual 221 cases the variability of $\mathrm{R}_{\text {int }}$ measurements is high (mean intra-patient CV 10.6\%), precluding 222 proper prediction of changes in $\mathrm{FEV}_{1}$. In the present study the ROC curve, describing the 223 sensitivity and specificity of $\mathrm{R}_{\text {int }}$ in detecting BHR as determined by the primary outcome $224 \mathrm{FEV}_{1}$, had a small AUC of 0.65 . This predictive capacity is lower compared to impulse 225 oscillometry (AUC 0.68 to $0.75(23)$ ).

226 Large individual fluctuations in $\mathrm{R}_{\text {int }}$ might be due to large intrapatient short-term 227 variation in airway resistance during tidal breathing $(11 ; 17 ; 20 ; 24)$. This variability, resulting 228 in low sensitivity and specificity, could limit the ability to detect thresholds in individual 229 airway obstruction as required in clinical practice. Furthermore the sensitivity might be lower 230 compared to $\mathrm{FEV}_{1}$ because during (severe) airflow obstruction equilibration of alveolar 231 pressure might take longer than is realised during the shutter closure time during $R_{\text {int }}$ 232 measurement (25). This may explain the lower $\mathrm{R}_{\text {int }}$ values in case of (severe) peripheral 233 airway obstruction and hence lead to misclassifications during methacholine challenge 234 testing. A third explanation of high variability of $\mathrm{R}_{\text {int }}$ might be the variability of upper airway 
235 resistance. Proper positioning of the head and neck and adequate support of the cheeks is 236 highly warranted and might lead to intra-individual variability.

237 The findings of our study imply that on group level BHR can be documented, since we

238 showed on average a significant rise in $\mathrm{R}_{\text {int }}$ with increasing methacholine doses. This may be

239 useful in epidemiologic research. However, $\mathrm{R}_{\text {int }}$ seems to have insufficient capacity to

240 diagnose BHR in individual patients and therefore it is of limited value in BHR measurements

241 in clinical practice.

242 A major strength of our study is the fact that the methacholine challenge test was

243 repeated after 26 weeks and resulted in a similarly low sensitivity and specificity of $R_{\text {int }}$,

244 which validated the results. Beside this, the present study may have some limitations. Firstly,

245 the study was performed in children with a mean age of 9.3 years, because preschool children

246 are seldom able to perform $\mathrm{FEV}_{1}$ measurements. It could be questioned if the found results

247 are applicable to younger children. Since $\mathrm{R}_{\mathrm{int}}$ is a measure of total airway resistance, an

248 induced bronchoconstriction will lead to a relative larger increase in $\mathrm{R}_{\text {int }}$ in young children

249 compared to older children, because in young children lower airways resistance contributes

250 more to total airway resistance (26). Nevertheless, the fluctuations in $\mathrm{R}_{\text {int }}$ are expected to be

251 similar as the short term repeatability of $R_{\text {int }}$ that has been found to be independent of age

252 (20;27). Additionally we used a 20\% fall as 'gold standard' in detecting methacholine induced

253 bronchoconstriction. When we used a $32 \%$ increase in $\mathrm{R}_{\text {int }}$ (the coefficient of repeatability of

$254 \mathrm{R}_{\text {int }}$ measurements as described by Beydon et al.) as a cut-off value to determine BHR, there

255 were 12 children with a significant change in $\mathrm{R}_{\text {int }}$ but without a $20 \%$ fall in $\mathrm{FEV}_{1}$. The

256 pathophysiology of a fall in $\mathrm{FEV}_{1}$ during a forced manoeuvre might be different from an

257 increase of $\mathrm{R}_{\mathrm{int}}$ during tidal breathing. Therefore, there is a possibility that $\mathrm{FEV}_{1}$ might not be

258 the gold standard for bronchial challenges especially in young children. 
1

3

4

5

6

8

10

11

12

13

14

15

16

17

18

19

20

21

22

23

24

25

26

27

28

29

30

31

32

33

34

35

36

37

38

39

40

41

42

43

44

45

46

47

48

49

50

51

52

53

54

55

56

57

58

59

60

259 The current study showed on average an increase of $\mathrm{R}_{\text {int }}$ with subsequent methacholine

260 doses during methacholine challenge tests and therefore it might be useful as a measure of

261 airflow obstruction in groups of patients, e.g. in large epidemiological studies. However, we

262 conclude that $\mathrm{R}_{\text {int }}$ seems to have insufficient capacity to diagnose BHR in individual patients. 263

264 


\section{ACKNOWLEDGEMENTS}

266 The authors would like to thank the lung function technicians for the measurements and the

267 members of the COMBO- $\mathrm{R}_{\text {int }}$ research group for recruiting the patients. The COMBO- $\mathrm{R}_{\text {int }}$

268 research group consists of: H.G.M. Arets (University Medical Centre Utrecht), N.J. van den

269 Berg (Flevo Hospital Almere), P.L.P. Brand (Princess Amalia Children's Hospital Zwolle),

270 E.J. Duiverman (University Medical Centre Groningen), H.J. Hendriks (Maastricht University

271 Medical Centre), J.W.C.M. Heynens (Maasland Hospital Sittard), J.C. van Nierop

272 (Academical Medical Centre Amsterdam), M. Nuysink (Juliana Children's Hospital).

273 HJL Brackel has received fees for consulting and for speaking from GlaxoSmithKline Pharma 274 Europe.

275

276 


\section{REFERENCES}

1. Bateman ED, Hurd SS, Barnes PJ, Bousquet J, Drazen JM, FitzGerald M, Gibson P,

Ohta K, O'Byrne P, Pedersen SE, Pizzichini E, Sullivan SD, Wenzel SE, Zar HJ.

Global strategy for asthma management and prevention: GINA executive summary.

282 Eur Respir J 2008 January;31(1):143-78.

2. Crapo RO, Casaburi R, Coates AL, Enright PL, Hankinson JL, Irvin CG, MacIntyre NR, McKay RT, Wanger JS, Anderson SD, Cockcroft DW, Fish JE, Sterk PJ.

Guidelines for methacholine and exercise challenge testing-1999. This official statement of the American Thoracic Society was adopted by the ATS Board of Directors, July 1999. Am J Respir Crit Care Med 2000 January;161(1):309-29.

3. Beydon N, Pin I, Matran R, Chaussain M, Boule M, Alain B, Bellet M, Amsallem F, Alberti C, Denjean A, Gaultier C. Pulmonary function tests in preschool children with asthma. Am J Respir Crit Care Med 2003 September 15;168(6):640-4.

4. Black J, Baxter-Jones AD, Gordon J, Findlay AL, Helms PJ. Assessment of airway function in young children with asthma: comparison of spirometry, interrupter technique, and tidal flow by inductance plethsmography. Pediatr Pulmonol 2004 June;37(6):548-53.

5. Beydon N, Davis SD, Lombardi E, Allen JL, Arets HG, Aurora P, Bisgaard H, Davis GM, Ducharme FM, Eigen H, Gappa M, Gaultier C, Gustafsson PM, Hall GL, Hantos Z, Healy MJ, Jones MH, Klug B, Lodrup Carlsen KC, McKenzie SA, Marchal F, Mayer OH, Merkus PJ, Morris MG, Oostveen E et al. An official American Thoracic Society/European Respiratory Society statement: pulmonary function testing in preschool children. Am J Respir Crit Care Med 2007 June 15;175(12):1304-45. 
301 6. Arets HG, Brackel HJ, van der Ent CK. Applicability of interrupter resistance

302 measurements using the MicroRint in daily practice. Respir Med 2003

$303 \quad$ April;97(4):366-74.

304 7. Klug B, Bisgaard H. Measurement of lung function in awake 2-4-year-old asthmatic 305 children during methacholine challenge and acute asthma: a comparison of the 306 impulse oscillation technique, the interrupter technique, and transcutaneous 307 measurement of oxygen versus whole-body plethysmography. Pediatr Pulmonol 1996 $308 \quad$ May;21(5):290-300.

309 8. Beydon N, Trang-Pham H, Bernard A, Gaultier C. Measurements of resistance by the 310 interrupter technique and of transcutaneous partial pressure of oxygen in young 311 children during methacholine challenge. Pediatr Pulmonol 2001 March;31(3):238-46.

312 9. Phagoo SB, Wilson NM, Silverman M. Evaluation of the interrupter technique for 313 measuring change in airway resistance in 5-year-old asthmatic children. Pediatr 314 Pulmonol 1995 December;20(6):387-95.

315 10. Phagoo SB, Wilson NM, Silverman M. Evaluation of a new interrupter device for 316 measuring bronchial responsiveness and the response to bronchodilator in 3 year old 317 children. Eur Respir J 1996 July;9(7):1374-80.

318 11. Bisgaard H, Klug B. Lung function measurement in awake young children. Eur Respir $319 \quad J 1995$ December;8(12):2067-75.

320 12. Vaessen-Verberne A.A.P.H., Berg van den N.J., Nierop van J.C., Brackel H.J.L., 321 Gerrits G.P.J.M., Hop W.C.J., Duiverman E.J. Combination therapy 322 salmeterol/fluticasone versus doubling dose of fluticasone in 323 children with asthma. Am.J.Respir.Crit Care Med. 2010 Jul 9. [Epub ahead of print] 
324 13. Miller MR, Hankinson J, Brusasco V, Burgos F, Casaburi R, Coates A, Crapo R, 325 Enright P, van der Grinten CP, Gustafsson P, Jensen R, Johnson DC, MacIntyre N, 326 McKay R, Navajas D, Pedersen OF, Pellegrino R, Viegi G, Wanger J. Standardisation 327 of spirometry. Eur Respir J 2005 August;26(2):319-38.

14. Birnie D, thoe Schwartzenberg GW, Hop WC, van Essen-Zandvliet EE, Kerrebijn KF. Does the outcome of the tidal breathing and dosimeter methods of assessing bronchial responsiveness in children with asthma depend on age? Thorax 1990 March;45(3):199-202.

15. Merkus PJ, Stocks J, Beydon N, Lombardi E, Jones M, McKenzie SA, Kivastik J, 333 Arets BG, Stanojevic S. Reference ranges for interrupter resistance technique: the 334 Asthma UK Initiative. Eur Respir J 2010 July;36(1):157-63.

16. Stanojevic S, Wade A, Stocks J, Hankinson J, Coates AL, Pan H, Rosenthal M, Corey 336 M, Lebecque P, Cole TJ. Reference ranges for spirometry across all ages: a new approach. Am J Respir Crit Care Med 2008 February 1;177(3):253-60.

17. Lombardi E, Sly PD, Concutelli G, Novembre E, Veneruso G, Frongia G, Bernardini 339 340 R, Vierucci A. Reference values of interrupter respiratory resistance in healthy preschool white children. Thorax 2001 September;56(9):691-5.

18. McKenzie SA, Chan E, Dundas I, Bridge PD, Pao CS, Mylonopoulou M, Healy MJ. Airway resistance measured by the interrupter technique: normative data for 2-10 year olds of three ethnicities. Arch Dis Child 2002 September;87(3):248-51.

19. Merkus PJ, Arets HG, Joosten T, Siero A, Brouha M, Mijnsbergen JY, de Jongste JC, van der Ent CK. Measurements of interrupter resistance: reference values for children 3-13 yrs of age. Eur Respir J 2002 October;20(4):907-11. 
347 20. Oswald-Mammosser M, Llerena C, Speich JP, Donata L, Lonsdorfer. Measurements 348 of respiratory system resistance by the interrupter technique in healthy and asthmatic 349 children. Pediatr Pulmonol 1997 August;24(2):78-85.

350 21. Kannisto S, Vanninen E, Remes K, Korppi M. Interrupter technique for evaluation of 351 exercise-induced bronchospasm in children. Pediatr Pulmonol 1999 March;27(3):2033527.

353 22. Davies PL, Doull IJ, Child F. The interrupter technique to assess airway 354 responsiveness in children with cystic fibrosis. Pediatr Pulmonol 2007 $355 \quad$ January;42(1):23-8.

356 23. Vink GR, Arets HG, van der LJ, van der Ent CK. Impulse oscillometry: a measure for 357 airway obstruction. Pediatr Pulmonol 2003 March;35(3):214-9.

358 24. Klug B, Bisgaard H. Specific airway resistance, interrupter resistance, and respiratory 359 impedance in healthy children aged 2-7 years. Pediatr Pulmonol 1998 May;25(5):32236031.

361 25. Bates JH, Sly PD, Kochi T, Martin JG. The effect of a proximal compliance on 362 interrupter measurements of resistance. Respir Physiol 1987 December;70(3):301-12.

363 26. Arets HG, van der Ent CK. Measurements of airway mechanics in spontaneously 364 breathing young children. Paediatr Respir Rev 2004 March;5(1):77-84.

365 27. Chan EY, Bridge PD, Dundas I, Pao CS, Healy MJ, McKenzie SA. Repeatability of 366 airway resistance measurements made using the interrupter technique. Thorax 2003 $367 \quad$ April;58(4):344-7. 


\section{FIGURE LEGENDS}

370

371 Figure 1. Mean changes from baseline of $\operatorname{FEV}_{\mathbf{1}}(\mathbf{1 A})$ and $\mathrm{R}_{\text {int }}(1 \mathrm{~B})$. At each dose step

372 patients are grouped according to whether (closed symbols) or not (open symbols) the $373 \mathbf{P D}_{\mathbf{2 0}}$ endpoint (20\% fall in $\left.\mathrm{FEV}_{\mathbf{1}}\right)$ was reached at that dose step. Error bars represent 374 SEM.

375

376 Figure 2. Individual changes from baseline of $\mathbf{R}_{\text {int }}$ at each dose step, divided according to 377 whether (closed symbols) or not (open symbols) the $\mathrm{PD}_{20}$ endpoint (20\% fall in FEV $\mathrm{FV}_{1}$ 378 was reached. At each dose step there is large overlap in changes from baseline of $\mathbf{R}_{\text {int }}$ 379 between both groups.

381 Figure 3. Receiver operator characteristic (ROC) curve showing the sensitivity and false 382 positive rate of the change from baseline of $R_{\text {int }}$ as a measure to detect a $20 \%$ fall in $383 \quad \mathrm{FEV}_{\mathbf{1}}\left(\mathrm{PD}_{\mathbf{2 0}}\right)$. Area under the curve $(\mathrm{AUC})=\mathbf{0 . 6 5}$. 
Table 1: Baseline characteristics of children with moderate asthma $(n=73)$ who performed a methacholine provocation test with both $R_{\text {int }}$ and $F E V_{1}$ measurement at first visit.

\begin{tabular}{|c|c|c|}
\hline & & Median (interquartile range) \\
\hline \multicolumn{2}{|l|}{ Age (years) } & $9.2(7.6-10.6)$ \\
\hline \multicolumn{2}{|l|}{ Height $(\mathrm{cm})$} & $135.6(128.5-146.0)$ \\
\hline \multicolumn{2}{|c|}{ Sex (number $(\%)$ males) } & $43(58.9 \%)$ \\
\hline \multirow[t]{2}{*}{$\mathrm{FEV}_{1}^{\mathrm{a}}$} & z-score & $-0.26(-0.74-0.32)$ \\
\hline & $\%$ predicted & $96.8(90.8-104.2)$ \\
\hline \multirow[t]{2}{*}{$\mathrm{FVC}^{\mathrm{b}}$} & z-score & $0.10(-0.37-0.67)$ \\
\hline & $\%$ predicted & $101.4(95.7-108.3)$ \\
\hline \multirow[t]{2}{*}{$\mathrm{FEV}_{1} / \mathrm{FVC}$} & Z-score & $-0.81(-1.34--0.21)$ \\
\hline & $\%$ predicted & $94.1(89.7-98.6)$ \\
\hline \multirow[t]{2}{*}{$\mathrm{R}_{\text {int }}{ }^{\mathrm{c}}$} & z-score & $0.78(0.05-1.57)$ \\
\hline & $\%$ predicted & $123.4(107.0-147.2)$ \\
\hline
\end{tabular}

a) $\mathrm{FEV}_{1}=$ Forced expiratory volume in 1 second; b) $\mathrm{FVC}=$ Forced expiratory volume; c) $\mathbf{R}_{\text {int }}=$ Interrupter resistance. 
Table 2: Number of children with moderate asthma $(n=73)$ who reached the $\mathbf{P D}_{20}$ endpoint $^{\text {a) }}$ at subsequent methacholine dose steps.

\begin{tabular}{rlr}
\hline Dose step & Number \\
$2=0.625 \mu \mathrm{g}$ & 0 \\
$3=2.25 \mu \mathrm{g}$ & 0 \\
$3=2.5 \mathrm{~g}$ & 2 \\
$4=5.0 \mu \mathrm{g}$ & 6 \\
$5=10.0 \mu \mathrm{g}$ & 10 \\
$6=20 \mu \mathrm{g}$ & 10 \\
$7=40 \mu \mathrm{g}$ & 10 \\
$8=80 \mu \mathrm{g}$ & 9 \\
$9=160 \mu \mathrm{g}$ & 9 \\
$10=320 \mu \mathrm{g}$ & 5 \\
No threshold & 21 \\
\hline
\end{tabular}

a) $\mathrm{PD}_{20}$ endpoint $=$ dose step at which a fall of more than $20 \%$ in $\mathrm{FEV}_{1}$ was reached. 
$1 \mathrm{~A}$

Figure 1. Mean changes from baseline of $\mathrm{FEV}_{1}(1 \mathrm{~A})$ and $\mathrm{R}_{\text {int }}(1 \mathrm{~B})$. At each dose step patients are grouped according to whether (closed symbols) or not (open symbols) the $\mathrm{PD}_{20}$ endpoint ( $20 \%$ fall in $\mathrm{FEV}_{1}$ ) was reached at that dose step. Error bars represent SEM. $179 \times 190 \mathrm{~mm}$ (96 x 96 DPI)

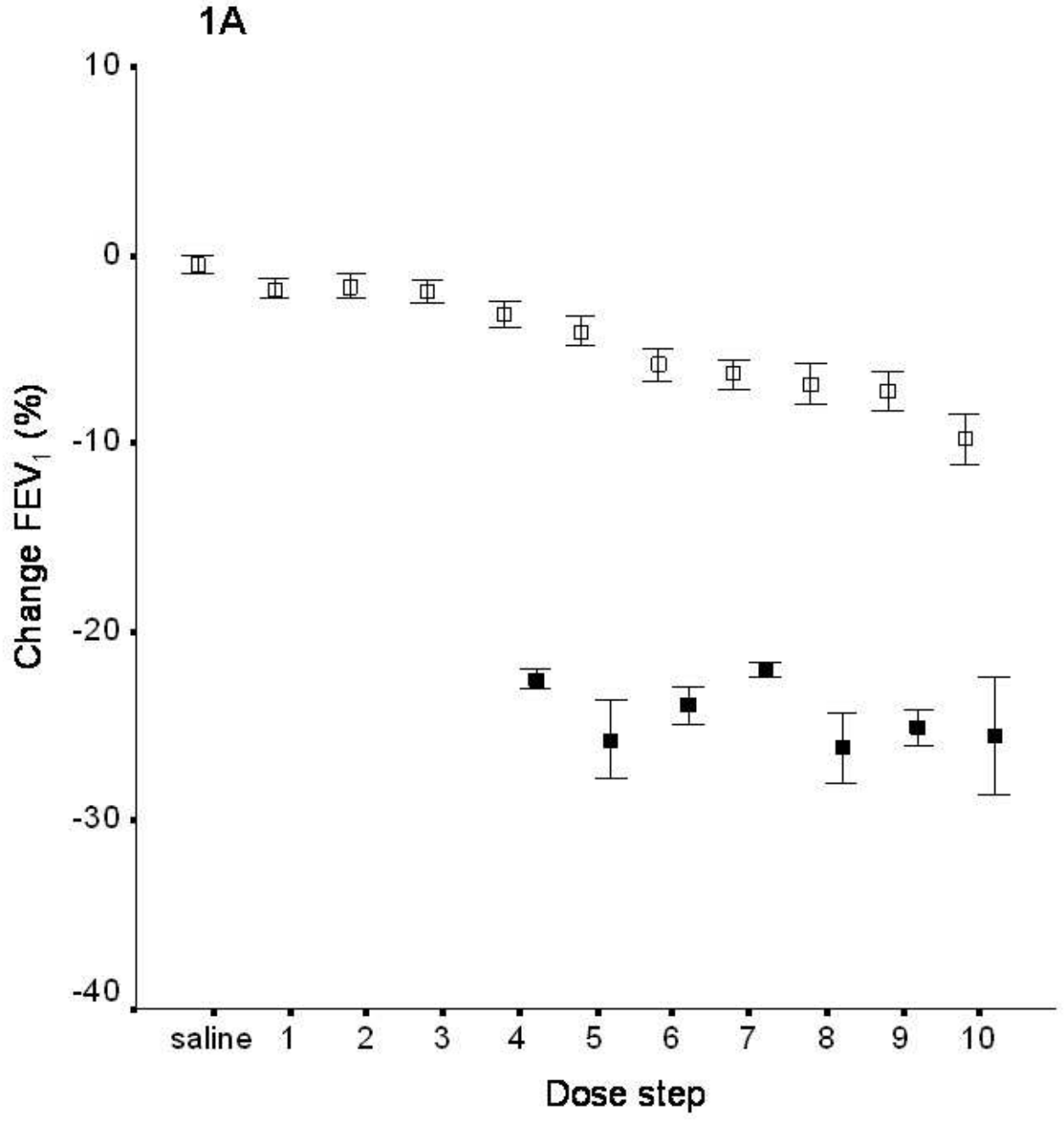


1B

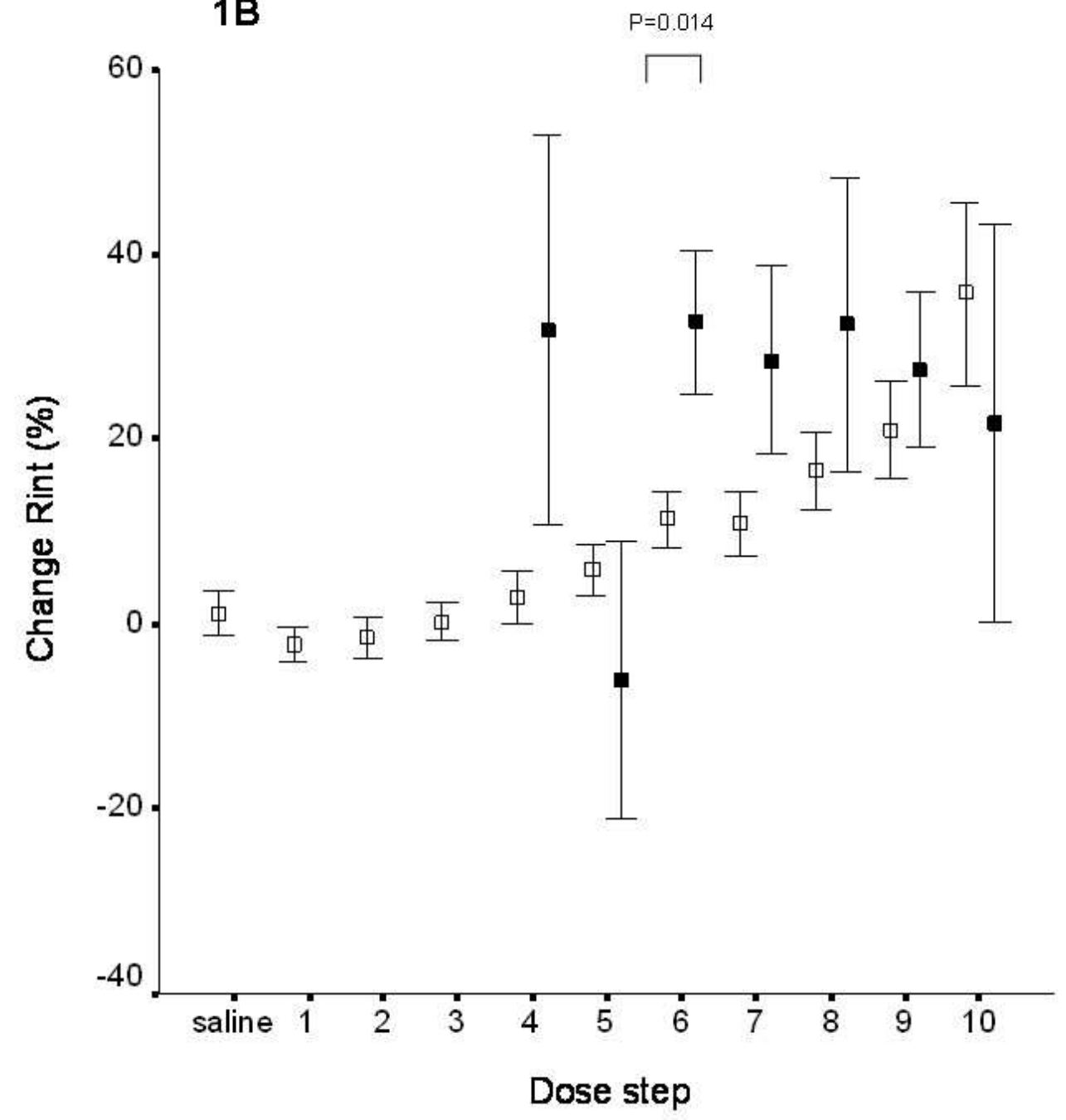

Figure 1. Mean changes from baseline of $\mathrm{FEV}_{1}(1 \mathrm{~A})$ and $\mathrm{R}_{\text {int }}(1 \mathrm{~B})$. At each dose step patients are grouped according to whether (closed symbols) or not (open symbols) the $\mathrm{PD}_{20}$ endpoint $(20 \%$ fall in $\mathrm{FEV}_{1}$ ) was reached at that dose step. Error bars represent SEM. $173 \times 190 \mathrm{~mm}(96 \times 96 \mathrm{DPI})$ 


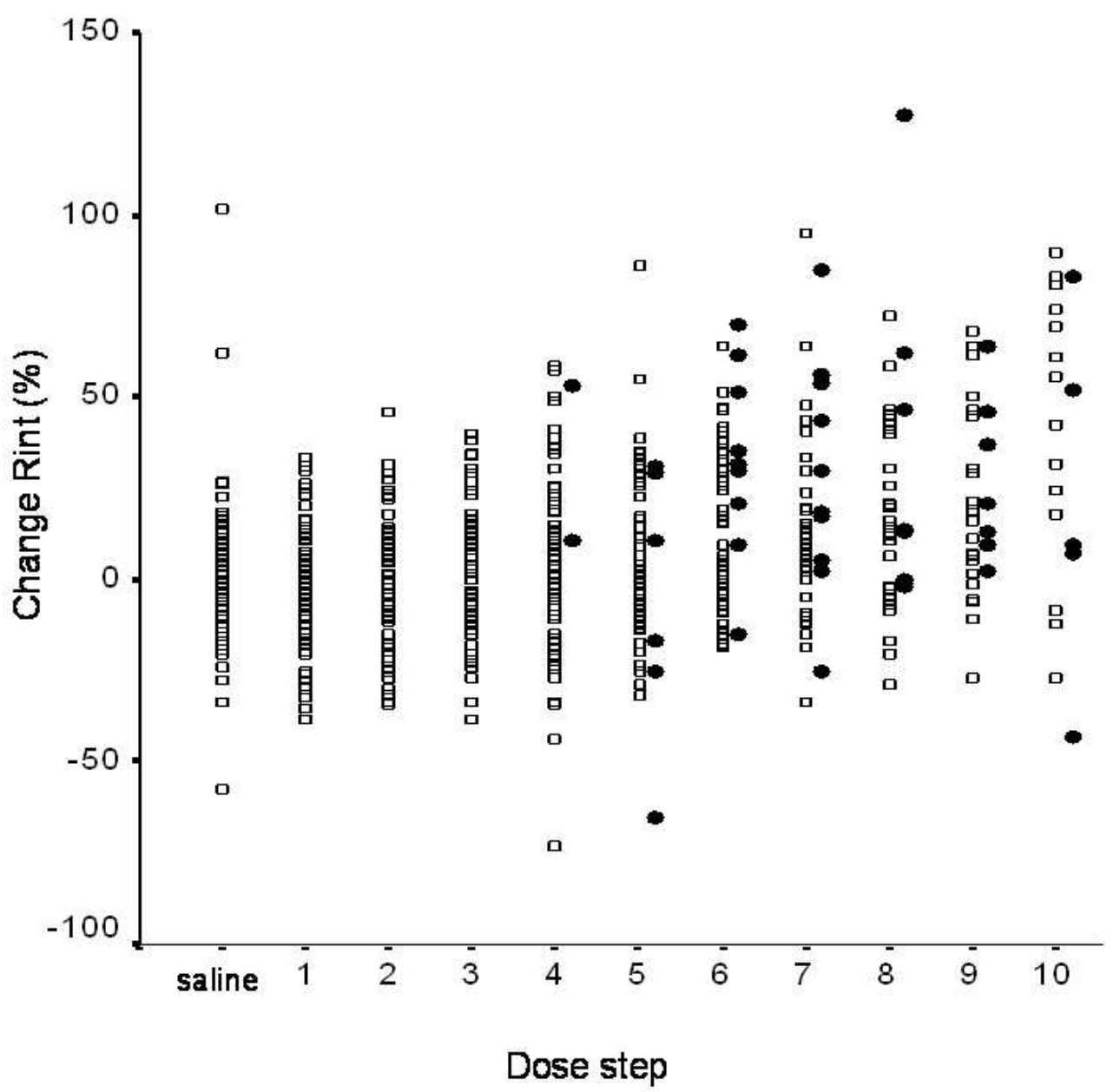

Figure 2. Individual changes from baseline of Rint at each dose step, divided according to whether (closed symbols) or not (open symbols) the $\mathrm{PD}_{20}$ endpoint ( $20 \%$ fall in $\mathrm{FEV}_{1}$ ) was reached. At each dose step there is large overlap in changes from baseline of $\mathrm{R}_{\text {int }}$ between both groups. $191 \times 190 \mathrm{~mm}$ (96 x 96 DPI) 


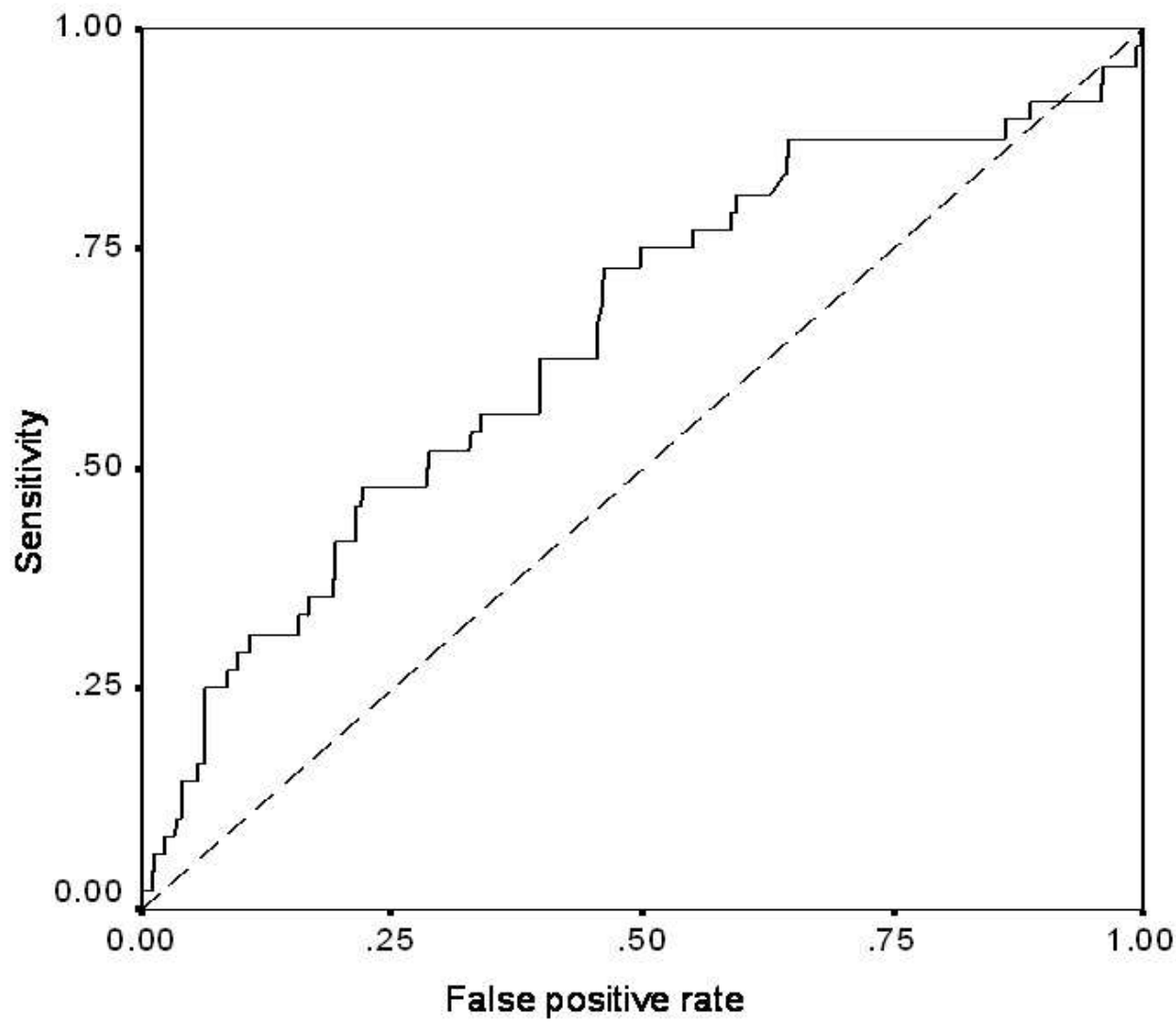

Figure 3. Receiver operator characteristic (ROC) curve showing the sensitivity and false positive rate of the change from baseline of $\mathrm{R}_{\text {int }}$ as a measure to detect a $20 \%$ fall in $\mathrm{FEV}_{1}\left(\mathrm{PD}_{20}\right)$. Area under the curve $(A \cup C)=0.65$. $186 \times 161 \mathrm{~mm}(96 \times 96 \mathrm{DPI})$ 


\section{ONLINE DATA SUPPLEMENT}

2

3 EVALUATION OF INTERRUPTER RESISTANCE IN METHACHOLINE CHALLENGE

4 TESTING IN CHILDREN

5

6 Authors: Marije Koopman, $\mathrm{MD}^{1}$; Hein J.L. Brackel, MD, $\mathrm{PhD}^{2}$; Anja A.P.H. Vaessen-

7 Verberne, $\mathrm{MD}, \mathrm{PhD}^{3}$; Wim C. Hop, $\mathrm{PhD}^{4}$; Cornelis K. van der Ent, $\mathrm{MD}, \mathrm{PhD}^{1}$; on behalf of

8 the COMBO-Rint research group.

9

10 Institutions:

11 1. Department of Paediatric Pulmonology, Wilhelmina Children's Hospital, University

12 Medical Centre Utrecht, Utrecht, the Netherlands.

13 2. Department of Paediatrics, Catharina Hospital, Eindhoven, the Netherlands.

14 3. Department of Paediatrics, Amphia Hospital, Breda, the Netherlands

15 4. Department of Biostatistics, Erasmus MC - University Medical

16 Centre Rotterdam, Rotterdam, the Netherlands

17

18 COMBO-Rint research group consists of: H.G.M. Arets, N.J. van den Berg, P.L.P. Brand,

19 E.J. Duiverman, H.J. Hendriks, J.W.C.M. Heynens, J.C. van Nierop, M. Nuysink.

21 Financial support: This study was supported by an unconditional grant from

22 GlaxoSmithKline Pharma Europe. 
23

24

25

\section{MATERIALS AND METHODS}

This study was a substudy performed in some centres participating in the multicentre COMBO-study. The COMBO-study is a blinded study comparing the clinical effects of fluticasone propionate $200 \mathrm{mcg}$ BD versus salmeterol/fluticasone propionate 50/100 mcg BD on number of symptoms free days in children between 6 and 16 years of age (trial registration number NCT00197106; GSK study number SAM101667) (1). It was performed in 158 patients in 19 hospitals in the Netherlands, between June 2005 and October 2008. All children had a clinical history of moderate asthma (according to NAEPP guidelines (2)) and bronchial hyperresponsiveness (BHR) (methacholine dose at which at least $20 \%$ fall in $\mathrm{FEV}_{1}\left(\mathrm{PD}_{20}\right) \leq$ $150 \mu \mathrm{g})$. Nine hospitals performed additional Rint measurements during methacholine challenge tests, so children from these centres were included in this comparative lung function study. The study was approved by the local medical ethical committees of the different centres and written informed consent was obtained from the parents (and also from the child if $\geq 12$ years old) before the start of the study.

\section{Measurements}

\section{Methacholine challenge testing}

Methacholine challenge tests were performed using the dosimeter method $(3 ; 4)$ with a nebulizer (model 646, DeVilbiss Healthcare, Somerset, USA) attached to a dosimeter (Rosenthal French dosimeter, PDS Instrumentation, Louisville CO, USA). After baseline $\mathrm{R}_{\text {int }}$ and $\mathrm{FEV}_{1}$ measurements, $0.9 \% \mathrm{NaCl}$ was inhaled to rule out non-specific reactions and additionally methacholine chloride was administered in doubling doses $(0.625 \mu \mathrm{g}, 1.25 \mu \mathrm{g}$, $2.5 \mu \mathrm{g}, 5.0 \mu \mathrm{g}, 10.0 \mu \mathrm{g}, 20.0 \mu \mathrm{g}, 40.0 \mu \mathrm{g}, 80 \mu \mathrm{g}, 160 \mu \mathrm{g}, 320 \mu \mathrm{g})$. The procedure was performed according to the latest ATS/ERS guidelines (4) as follows: after manually triggering of the dosimeter children were instructed to inhale slowly from forced residual 
capacity (FRC) to total lung capacity (TLC) and then hold their breath for 2 seconds. Two minutes after each inhalation, $\mathrm{R}_{\mathrm{int}}$ and $\mathrm{FEV}_{1}$ were measured. Provocation was continued after at least five minutes and until the $\mathrm{PD}_{20}$ or the maximum dose was reached.

\section{Interrupter resistance}

Airway resistance measurements were carried out using the MicroRint (Micro Medical

Limited, Kent, UK) that contains a pneumotachometer, a flow interruption valve and a pressure transducer to measure mouth pressure post-occlusion. A bacterial filter was used (Spirosafe bacterial filter, Micro Medical, Kent, UK). Measurements were performed conform the latest ATS/ERS guideline (5). The child was seated and diverted to ensure quiet tidal breathing. Children were breathing through a mouth piece while the technicians supported the cheeks to reduce the change in upper airway compliance. Ten interruptions of $100 \mathrm{~ms}$ were made at peak expiratory flow with a random frequency, with the valve closing within $10 \mathrm{~ms}$. The MicroRint software automatically rejected measurements that showed an artefact on the pressure curve. Additionally measurements that showed tachypnoea or irregular breathing, vocalisation, or hyperextension or flexion of the neck were manually discarded as well as were tracings with a horizontal or declining pressure signal suggesting air leakage around the mouthpiece. $\mathrm{R}_{\text {int }}$ values were calculated using the two-point linear fit back extrapolation technique to $t=15 \mathrm{~ms}$ (6). A minimum of five successful interruptions was required to calculate the median $R_{\text {int }}$ value. Reference values of Merkus et al. (7) were used to convert $R_{\text {int }}$ outcomes into percentage predicted values.

\section{Spirometry}

Maximal expiratory flow-volume measurements were performed with standardized equipment. Seven centres used a Jaeger pneumotachometer (Viasys Healthcare, Hochberg, 
73 Germany), 1 centre used the Microloop (Micro Medical, Kent, UK) and 1 centre used a Zan

74 spirometer (nSpire Health GmbH, Oberthulba, Germany). Measurements were performed

75 according to the latest ATS/ERS guidelines (8) with the child sitting and wearing a nose clip,

76 without using a bacterial filter. Equipment calibration was performed daily and all

77 measurements were BTPS corrected. After a full inspiration children performed a maximally

78 forced and full expiration. At least three technician-accepted flow-volume curves were

79 obtained and the largest $\mathrm{FEV}_{1}$ was selected. Reference values of Stanojevic (9) were used.

80

Analysis; Calculation of intrapatient coefficients of variation (CV):

To quantify the variability of $\mathrm{FEV}_{1}$ and $\mathrm{R}_{\text {int }}$ measurements between the various dose steps

during the methacholine provocation test, a coefficient of variation $(\mathrm{CV})$ was calculated for each separate patient. This was done by fitting smooth third degree polynomials of each parameter separately versus log-methacholine dose for each individual patient to allow a gradual change over the subsequent dose steps. The resulting standard deviation of residuals for each patient was subsequently divided by the same patients mean value to obtain an individual $\mathrm{CV}$ of the measurements. The resulting individual paired CV's of $\mathrm{FEV}_{1}$ and $\mathrm{R}_{\text {int }}$ were compared using Wilcoxon's test.

\section{RESULTS}

92 Visual inspection of individual $\mathrm{R}_{\text {int }}$ profiles during the challenge test showed large

93 fluctuations with rises and falls at subsequent dose steps. In contrast, much smoother profiles 94 with gradual falls were found for $\mathrm{FEV}_{1}$ (E-figure 1). 
96

97

98

99

100

101

102

103

104

105

106

107

108

109

110

111

112

113

114

115

116

117

\section{E-REFERENCES}

E1. Vaessen-Verberne A.A.P.H., Berg van den N.J., Nierop van J.C., Brackel H.J.L., Gerrits G.P.J.M., Hop W.C.J., Duiverman E.J. Combination therapy salmeterol/fluticasone versus doubling dose of fluticasone in children with asthma. Am.J.Respir.Crit Care Med. Accepted for publication. 2010.

E2. Expert Panel Report 3 (EPR-3): Guidelines for the Diagnosis and Management of Asthma-Summary Report 2007. J Allergy Clin Immunol 2007 November;120(5 Suppl):S94-138.

E3. Birnie D, thoe Schwartzenberg GW, Hop WC, van Essen-Zandvliet EE, Kerrebijn KF. Does the outcome of the tidal breathing and dosimeter methods of assessing bronchial responsiveness in children with asthma depend on age? Thorax 1990 March;45(3):199-202.

E4. Crapo RO, Casaburi R, Coates AL, Enright PL, Hankinson JL, Irvin CG, MacIntyre NR, McKay RT, Wanger JS, Anderson SD, Cockcroft DW, Fish JE, Sterk PJ. Guidelines for methacholine and exercise challenge testing-1999. This official statement of the American Thoracic Society was adopted by the ATS Board of Directors, July 1999. Am J Respir Crit Care Med 2000 January;161(1):309-29.

E5. Beydon N, Davis SD, Lombardi E, Allen JL, Arets HG, Aurora P, Bisgaard H, Davis GM, Ducharme FM, Eigen H, Gappa M, Gaultier C, Gustafsson PM, Hall GL, Hantos Z, Healy MJ, Jones MH, Klug B, Lodrup Carlsen KC, McKenzie SA, Marchal F, Mayer OH, Merkus PJ, Morris MG, Oostveen E et al. An official American Thoracic 
118 Society/European Respiratory Society statement: pulmonary function testing in 119 preschool children. Am J Respir Crit Care Med 2007 June 15;175(12):1304-45.

120 E6. Phagoo SB, Wilson NM, Silverman M. Evaluation of the interrupter technique for 121 measuring change in airway resistance in 5-year-old asthmatic children. Pediatr Pulmonol 1995 December;20(6):387-95.

123 E7. Merkus PJ, Stocks J, Beydon N, Lombardi E, Jones M, McKenzie SA, Kivastik J, 124 Arets BG, Stanojevic S. Reference ranges for interrupter resistance technique: the 125 asthma UK initiative. Eur Respir J 2010 July;36(1):157-63.

126 E8. Miller MR, Hankinson J, Brusasco V, Burgos F, Casaburi R, Coates A, Crapo R, 127 Enright P, van der Grinten CP, Gustafsson P, Jensen R, Johnson DC, MacIntyre N, 128 McKay R, Navajas D, Pedersen OF, Pellegrino R, Viegi G, Wanger J. Standardisation 129 of spirometry. Eur Respir J 2005 August;26(2):319-38.

130 E9. Stanojevic S, Wade A, Stocks J, Hankinson J, Coates AL, Pan H, Rosenthal M, Corey 131 M, Lebecque P, Cole TJ. Reference ranges for spirometry across all ages: a new 132 approach. Am J Respir Crit Care Med 2008 February 1;177(3):253-60. 


\section{E-FIGURE LEGEND}

136 E-figure 1. Individual fluctuations of absolute values of $\operatorname{FEV}_{1}(\mathrm{E} 1 \mathrm{~A})$ and $\mathbf{R}_{\text {int }}(\mathrm{E} 1 \mathrm{~B})$

137 plotted against dose steps of methacholine in 73 children with moderate asthma. Dose 138 step 0.5 denotes Saline.

139

140 


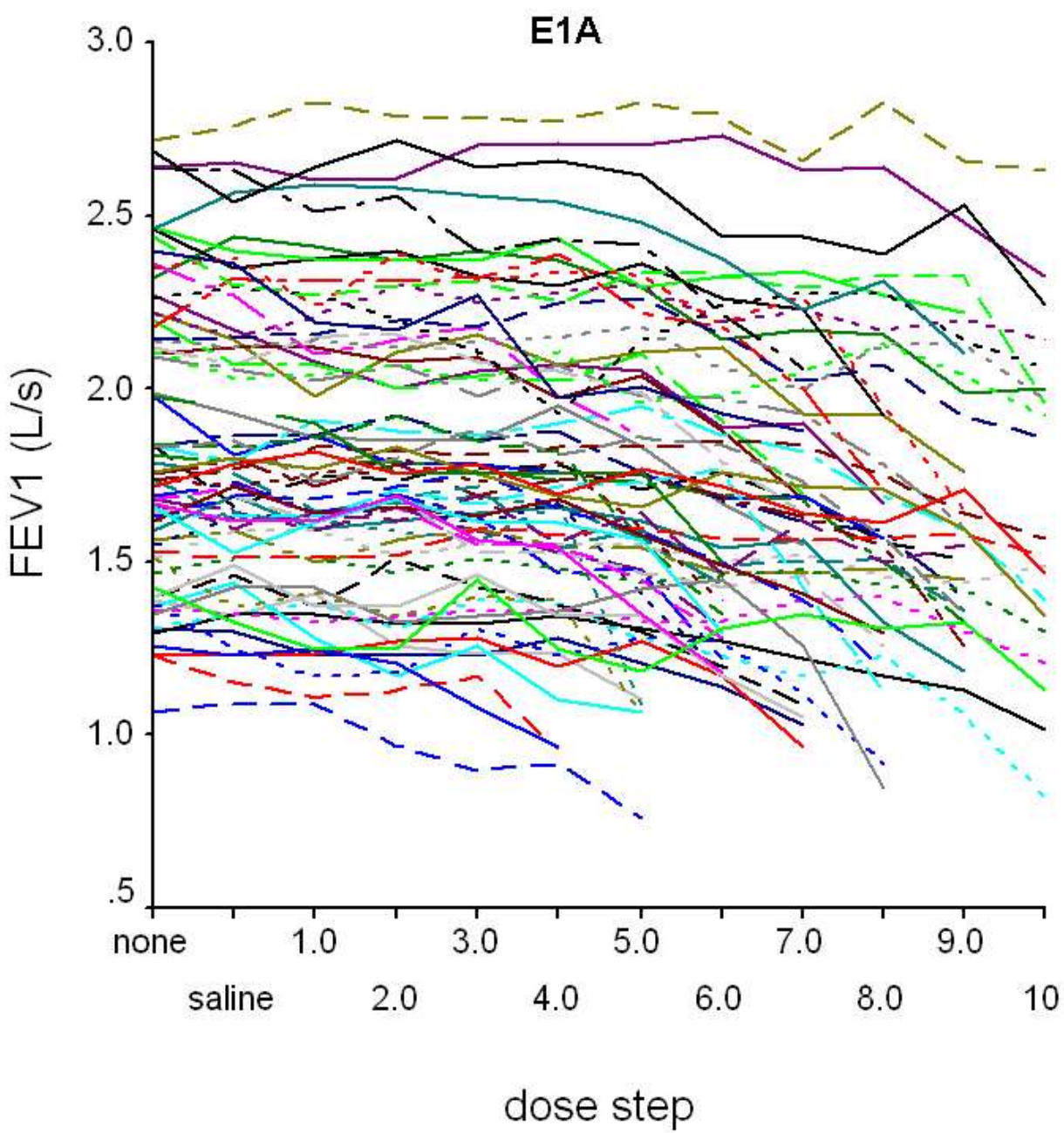

E-figure 1. Individual fluctuations of absolute values of FEV $1(E 1 A)$ and $R_{\text {int }}(E 1 B)$ plotted against dose steps of methacholine in 73 children with moderate asthma. Dose step 0.5 denotes Saline. $190 \times 196 \mathrm{~mm}(96 \times 96$ DPI)

John Wiley \& Sons, Inc. 


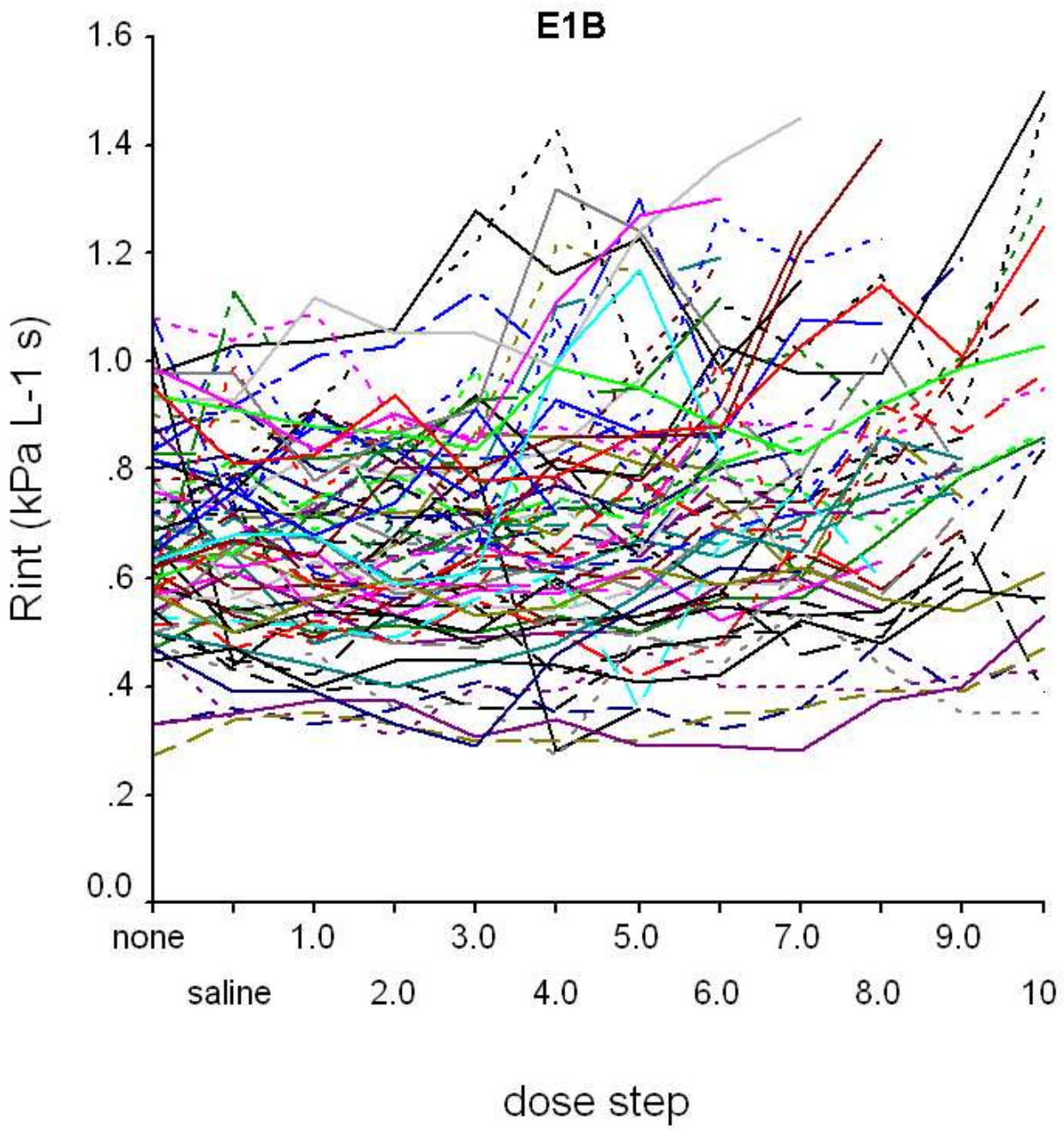

E-figure 1. Individual fluctuations of absolute values of $F E V_{1}(E 1 A)$ and $R_{\text {int }}(E 1 B)$ plotted against dose steps of methacholine in 73 children with moderate asthma. Dose step 0.5 denotes Saline. $190 \times 199 \mathrm{~mm}(96 \times 96$ DPI $)$ 